H A R VAR D

\title{
Clusters of Entrepreneurship
}

Edward L. Glaeser

William R. Kerr

Giacomo A. M. Ponzetto

\section{Working Paper}

10-019 


\title{
Clusters of Entrepreneurship ${ }^{1}$
}

\author{
Edward L. Glaeser \\ Harvard University and NBER \\ William R. Kerr ${ }^{2}$ \\ Harvard Business School \\ Giacomo A. M. Ponzetto \\ CREI and Universitat Pompeu Fabra
}

September 2009

\footnotetext{
${ }^{1}$ Comments are appreciated and can be sent to eglaeser@harvard.edu, wkerr@hbs.edu, and gponzetto@crei.cat. Kristina Tobio provided excellent research assistance. We thank Zoltan J. Acs, Jim Davis, Mercedes Delgado, Stuart Rosenthal, Will Strange, and participants of the Cities and Entrepreneurship conference for advice on this paper. This research is supported by Harvard Business School, the Kauffman Foundation, the National Science Foundation, and the Innovation Policy and the Economy Group. The research in this paper was conducted while the authors were Special Sworn Status researchers of the US Census Bureau at the Boston Census Research Data Center (BRDC). Support for this research from NSF grant (ITR-0427889) is gratefully acknowledged. Research results and conclusions expressed are our own and do not necessarily reflect the views of the Census Bureau or NSF. This paper has been screened to insure that no confidential data are revealed.

${ }^{2}$ Corresponding author: Rock Center 212, Harvard Business School, Boston, MA 02163; 617-4967021; wkerr@hbs.edu.
} 


\begin{abstract}
Employment growth is strongly predicted by smaller average establishment size, both across cities and across industries within cities, but there is little consensus on why this relationship exists. Traditional economic explanations emphasize factors that reduce entry costs or raise entrepreneurial returns, thereby increasing net returns and attracting entrepreneurs. A second class of theories hypothesizes that some places are endowed with a greater supply of entrepreneurship. Evidence on sales per worker does not support the higher returns for entrepreneurship rationale. Our evidence suggests that entrepreneurship is higher when fixed costs are lower and when there are more entrepreneurial people.
\end{abstract}

JEL Classification: J2, L0, L1, L2, L6, O3, R2.

Key Words: Entrepreneurship, Industrial Organization, Chinitz, Agglomeration, Clusters, Cities. 


\section{Introduction}

Economic growth is highly correlated with an abundance of small, entrepreneurial firms. Figure 1 shows that a 10\% increase in the number of firms per worker in 1977 at the city level correlates with a 9\% increase in employment growth between 1977 and 2000. This relationship is even stronger looking across industries within cities. This relationship has been taken as evidence for competition spurring technological progress (Glaeser et al., 1992), product cycles where growth is faster at earlier stages (Miracky, 1993), and the importance of entrepreneurship for area success (Acs and Armington, 2006; Glaeser, 2007). Any of these interpretations is compatible with Figure 1's correlation, however, and the only thing that we can be sure of is that entrepreneurial clusters exist in some areas but not in others.

We begin by documenting systematically some basic facts about average establishment size and new employment growth through entrepreneurship. We analyze entry and industrial structures at both the region and city levels using the Longitudinal Business Database. Section 2 confirms that the strong correlation in Figure 1 holds true under stricter frameworks and when using simple spatial instruments for industrial structures. A $10 \%$ increase in average establishment size in 1992 associates with a 7\% decline in subsequent employment growth due to new startups. Employment growth due to facility expansions also falls by almost 5\%. We further document that these reductions come primarily through weaker employment growth in small entrants.

What can explain these spatial differences? We first note that the connection between average establishment size and subsequent entrepreneurship is empirically stronger at the city-industry level than on either dimension individually. This suggests that simple theories emphasizing just industry-wide or city-wide forces are insufficient. Theories must instead build upon particular city-industry traits or on endogenous spatial sorting and organizational forms due to interactions of city traits with industry traits.

We consider three broad rationales. The first two theories emphasize spatial differences in net returns to entrepreneurship, while the last theory emphasizes spatial differences in the supply of entrepreneurs. The former theories are more common among economists. They assume that entrepreneurs choose locations and compete within a national market, so that the supply of entrepreneurship is constant over space. This frictionless setting would not hold for concrete manufacturing, of course, but would be a good starting point for many industries. Entrepreneurship is then evident where firm profits are higher or where fixed costs are lower, either of which increases the net returns to opening a new business.

These spatial differences could be due to either exogenous or endogenous forces. To take Silicon Valley as an example, one story would suggest that Silicon Valley's high rate of entrepreneurship over the past 30 years was due to abnormal returns in California's computer sector as the industry took off. These returns would need to have been greater than California's and the 
computer industry's returns generally, perhaps descending from a technological breakthrough outside of the existing core for the industry (e.g., Duranton, 2007; Kerr, this issue).

On the other hand, Saxenian's (1994) classic analysis of Silicon Valley noted its abundance of smaller, independent firms relative to Boston's Route 128 corridor. Following Chinitz (1961) and Jacobs (1970), Saxenian argued that these abundant small firms themselves caused further entrepreneurship by lowering the effective cost of entry through the development of independent suppliers, venture capitalists, entrepreneurial culture, and so on. While distinct, both of these perspectives argue that spatial differences in net returns to entrepreneurship are responsible for the differences in entrepreneurship rates that we see empirically.

An alternative class of theories, which Chinitz also highlighted, is that the supply of entrepreneurship differs across space. Heterogeneity in supply may reflect historical accident or relatively exogenous variables. William Shockley's presence in Silicon Valley was partly due to historical accident (Shockley's mother), and entrepreneurs can be attracted to California's sunshine and proximity to Stanford independent of differences in net returns. Several empirical studies find entrepreneurs are more likely to be from their region of birth than wage workers, and that local entrepreneurs operate stronger businesses (e.g., Figueiredo et al., 2002; Michelacci and Silva, 2007). Immobile workers may possess traits that lend them to entrepreneurship (e.g., high human capital). Although quite different internally, these theories broadly suggest that semi-permanent differences in entrepreneurial supply exist spatially. ${ }^{1}$

While theories of the last kind are deserving of examination, they do not fit easily into basic economic models that include both firm formation and location choice. Section 3 presents just such a model that draws on Dixit and Stiglitz (1977). The baseline model illustrates the first class of theories that focus on the returns to entrepreneurship, as well as the difficulties of reconciling heterogeneity in entrepreneurial supply with the canonical framework of spatial economics. Two basic, intuitive results are that there will be more startups and smaller firms in sectors or areas where the fixed costs of production are lower or where the returns to entrepreneurship are higher. In the model, higher returns are due to more inelastic demand. A third result formalizes Chinitz's logic that entrepreneurship will be higher in places that have exogenously come to have more independent suppliers. Multiple equilibria are possible where some cities end up with a smaller number of vertically integrated firms, like Pittsburgh, and others end up with a larger number of independent firms.

But, our model breaks with Chinitz by assuming a constant supply of entrepreneurs across space. While we assume that skilled workers play a disproportionately large role in entrepreneurship, we also require a spatial equilibrium that essentially eliminates heterogeneity in entrepreneurship supply. In a sense, the model and our subsequent empirical work show how far one can get without assuming that the supply of entrepreneurship differs across space (due to

\footnotetext{
${ }^{1}$ These explanations are not mutually exclusive, especially in a dynamic setting. Areas that develop entrepreneurial clusters due to net returns may acquire attributes that promote a future supply of entrepreneurs independent of the factors.
} 
one or more of the potential theories). We operationalize this test by trying to explain away the average establishment size effect.

Section 4 presents evidence on these hypotheses. Our first tests look at sales per worker among small firms as a proxy for the returns to entrepreneurship. The strong relationship between initial industry structure and subsequent entry does not extend to entrepreneurial returns. While some entrepreneurial clusters are likely to be demand driven, the broader patterns suggest that higher gross returns do not account for the observed link between lower initial establishment size and subsequent entry prevalent in all sectors. We likewise confirm that differences in product cycles or region-industry age do not account for the patterns. These results are more compatible with views emphasizing lower fixed costs or a greater supply of entrepreneurs.

Our next two tests show that costs for entrepreneurs matter. Holding city-industry establishment size constant, subsequent employment growth is further aided by small establishments in other industries within the city. This result supports the view that having small independent suppliers and customers is beneficial for entrepreneurship (e.g., Glaeser and Kerr, 2009). We find a substantially weaker correlation between city-level establishment size and the facility growth of existing firms, which further supports this interpretation. We also use labor intensity at the region-industry level to proxy for fixed costs. We find a strong positive correlation between labor intensity and subsequent startup growth, which again supports the view that fixed costs are important. However, while individually powerful, neither of these tests explains away much of the basic establishment size effect.

We finally test sorting hypotheses. The linkage between employment growth and small establishment size is deeper than simple industry-wide or city-wide forces like entrepreneurs generally being attracted to urban areas with lots of amenities. Instead, as our model suggests, we look at interactions between city-level characteristics and industry-level characteristics. For example, the model suggests that entrepreneurship will be higher and establishment size lower in high amenity places among industries with lower fixed costs. The evidence supports several hypotheses suggested by the model, but controlling for different forces again does little to explain away the small establishment size effect. Neither human capital characteristics of the area nor amenities can account for much of the observed effect.

In summary, our results document the remarkable correlation between average initial establishment size and subsequent employment growth due to startups. The evidence does not support the view that this correlation descends from regional differences in demand for entrepreneurship. The data are more compatible with differences in entrepreneurship being due to cost factors, but our cost proxies still do not explain much of the establishment size effect. Our results are also compatible with the Chinitz view that some places just have a greater supply of entrepreneurs, although this supply must be something quite different from the overall level of human capital. We hope that future work will focus on whether the small establishment size effect reflects entrepreneurship supply or heterogeneity in fixed costs that we have been unable 
to capture empirically. ${ }^{2}$

\section{Clusters of Competition and Entrepreneurship}

We begin with a description of the Longitudinal Business Database (LBD). We then document a set of stylized facts about employment growth due to entrepreneurship. These descriptive pieces particularly focus on industry structure and labor intensity to guide and motivate the development of our model in Section 3.

\subsection{LBD and US Entry Patterns}

The LBD provides annual observations for every private-sector establishment with payroll from 1976 onward. The Census Bureau data are an unparalleled laboratory for studying entrepreneurship rates and the life cycles of US firms. Sourced from US tax records and Census Bureau surveys, the micro-records document the universe of establishments and firms rather than a stratified random sample or published aggregate tabulations. In addition, the LBD lists physical locations of establishments rather than locations of incorporation, circumventing issues related to higher legal incorporations in states like Delaware. Jarmin and Miranda (2002) describe the construction of the LBD.

The comprehensive nature of the LBD facilitates complete characterizations of entrepreneurial activity by cities and industries, types of firms, and establishment entry sizes. Each establishment is given a unique, time-invariant identifier that can be longitudinally tracked. This allows us to identify the year of entry for new startups or the opening of new plants by existing firms. We define entry as the first year in which an establishment has positive employment. We only consider the first entry for cases in which an establishment temporarily ceases operations (e.g., seasonal firms, major plant retoolings) and later re-enters the LBD. Second, the LBD assigns a firm identifier to each establishment that facilitates a linkage to other establishments in the LBD. This firm hierarchy allows us to separate new startups from facility expansions by existing multi-unit firms.

Table 1 characterizes entry patterns from 1992 to 1999. The first column refers to all new establishment formations. The second column looks only at those establishments that are not part of an existing firm in the database, which we define as entrepreneurship. The final column

\footnotetext{
${ }^{2}$ In a study of entrepreneurship in the manufacturing sector, Glaeser and Kerr (2009) found that the Chinitz effect was a very strong predictor of new firm entry. The effect dominated other agglomeration interactions among firms or local area traits. This paper seeks to measure this effect for other sectors and assess potential forces underlying the relationship. As such, this paper is also closely related and complementary to the work of Rosenthal and Strange (2009) using Dun and Bradstreet data. Beyond entrepreneurship, Drucker and Feser (2007) consider the productivity consequences of the Chinitz effect in the manufacturing sector, and $\mathrm{Li}$ and $\mathrm{Yu}$ (2009) provide evidence from China. Prior work on entry patterns using the Census Bureau data include Davis et al. (1996), Delgado et al. (2008, 2009), Dunne et al. (1989a, 1989b), Haltiwanger et al. (this issue), and Kerr and Nanda (2009a, 2009b).
} 
looks at new establishments that are part of an existing firm, which we frequently refer to as facility expansions.

Over the sample period, there were on average over 700,000 new establishments per annum, with 7.3 million employees. Single-unit startups account for $80 \%$ of new establishments but only $53 \%$ of new employment. Facility expansions are, on average, about 3.6 times larger than new startups. Table 1 documents the distribution of establishment entry sizes for these two types. Over $75 \%$ of new startups begin with five or fewer employees, versus fewer than half of entrants for expansion establishments of existing firms. About $0.5 \%$ of independent startups begin with more than 100 workers, compared to $4 \%$ of expansion establishments.

Across industries, startups are concentrated in services (39\%), retail trade (23\%), and construction (13\%). Facility expansions are concentrated in retail trade (32\%), services (30\%), and finance, insurance, and real estate (18\%). The growing region of the South has the most new establishment formations, and regional patterns across the two classes of new establishments are quite similar. This uniformity, however, masks the agglomeration that frequently exists at the industry level. Well-known examples include the concentration of the automotive industry in Detroit, tobacco in Virginia and North Carolina, and high-tech entrepreneurship within regions like Silicon Valley and Boston's Route 128.

\subsection{Industry Structure and Entrepreneurship}

Table 2 shows the basic fact that motivates this paper: the correlation between average establishment size and employment growth. We use both regions and metropolitan areas for spatial variation in this paper. While we prefer to analyze metropolitan areas, the city-level data become too thin for some of our variables when we use detailed industries. The dependent variable in the first three columns is the log employment growth in the region-industry due to new startups. The dependent variable for the second set of three columns is the log employment growth in the region-industry due to new facility expansions that are part of existing firms.

Panel A uses the log of average establishment size in the region-industry as the key independent variable. Panel B uses the Herfindahl-Hirschman Index (HHI) in the region-industry as our measure of industrial concentration. Regressions include the initial period's employment in the region as a control variable. For each industry, we exclude the region with the lowest level of initial employment. This excluded region-industry is employed in the instrumental variable specifications. Crossing eight regions and 349 SIC3 industries yields 2,712 observations as not every region includes all industries. Estimations are unweighted and cluster standard errors by industry.

The first regression, in the upper left hand corner of the table, shows that the elasticity of employment growth in startups to initial employments is 0.97 . This suggests that, holding mean establishment size constant, the number of startups scales almost one-for-one with existing employment. The elasticity of birth employment with respect to average establishment size in the 
region-industry is -0.67 . This relationship is both large and precisely estimated. It suggests that, holding initial employments constant, a 10\% increase in average establishment size is associated with a $7 \%$ decline in the employment growth in new startups. These initial estimates control for region fixed effects (FEs) but not for industry FEs. Column 2 includes industry FEs so that all of the variation is coming from regional differences within an industry. The coefficient on average establishment size of -0.64 is remarkably close to that estimated in Column 1 .

In the third regression, we instrument for observed average establishment size using the mean establishment size in the excluded region by industry. This instrument strategy only exploits industry-level variation, so we cannot include industry FEs. The estimated elasticities are again quite similar. These instrumental specifications suggest that the central relationship is not purely due to local feedback effects, where a high rate of growth in one particular region leads to an abundance of small firms in that place. Likewise, the relationship is not due to measuring existing employment and average establishment size from the same data.

Panel B of Table 2 considers the log HHI index of concentration within each region-industry. While the model in the next section suggests using average establishment size to model industrial structure, there is also a long tradition of empirically modeling industrial structure through HHI metrics. $^{3}$ The results using this technique are quite similar to Panel A. A 10\% increase in region-industry concentration in 1992 is associated with a $4 \%$ decline in employment due to new startups over 1992-1999. The coefficient on initial region-industry employment, however, is lower in this case. When not controlling for initial establishment size, there is a less than one-for-one relationship between initial employment and later growth through startups.

Column 2 of Panel B again models industry FEs. The coefficients are less stable than in the upper panel. The elasticity of startup employment to the HHI index continues to be negative and extremely significant, but it loses over $50 \%$ of its economic magnitude compared to the first column. Column 3 instruments using the concentration level in the omitted region. The results here are quite similar to those in the first column.

Columns 4 to 6 of Table 2 consider employment growth from new facility expansions by multiunit firms instead of new startups. These new establishments are not new entrepreneurship per se, but instead represent existing firms opening new production facilities, sales offices, and similar operations. Nevertheless, formations of new establishments represent more discontinuous events than simple employment growth at existing plants. Again, there is a strong negative effect of mean establishment size in the region-industry and subsequent employment growth due to facility expansions. The effect, however, is weaker than in the startup regressions. The results are basically unchanged when we include industry FEs or in the instrumental variables regression. These conclusions are also mirrored in Panel B's estimations using HHI concentration measures.

\footnotetext{
${ }^{3}$ The appendix also reports estimations using the share of employees in a region-industry working in establishments with 20 employees or fewer. This modelling strategy delivers similar results to mean establishment size or HHI concentration.
} 


\subsection{Variations by Sector}

Figures $2 \mathrm{a}$ and $2 \mathrm{~b}$ document estimations of the relationship between establishment entry rates and initial region-industry structure by sector. The underlying regressions, which are reported in the appendix, include region and industry FEs and control for log initial employment in region-industry. The squares document the point estimates, and the lines provide confidence bands of two standard errors. Negative coefficients again associate greater entry over 1992-1999 with smaller average establishment size by region-industry in 1992 .

Figure 2a shows that the average establishment size effect is present for startups in all sectors to at least a $10 \%$ confidence level. The elasticity is largest and most precisely estimated for manufacturing at greater than -0.8; the elasticity estimate for finance, insurance, and real estate is the weakest but still has a point estimate of -0.2 . On the other hand, Figure $2 \mathrm{~b}$ shows the average establishment effect is only present for facility expansions in manufacturing, mining, and construction. This relative concentration in manufacturing is striking, as this sector was the subject of the original Chinitz study and much of the subsequent research. The difference in levels between Figures $2 \mathrm{a}$ and $2 \mathrm{~b}$ also speaks to concentration among startups - in every sector, the average establishment size effect is largest for new entrepreneurs. ${ }^{4}$

\subsection{Entry Size Distribution}

Table 3 quantifies how these effects differ across establishment entry sizes. Table 1 shows that most new establishments are quite small, while others have more than 100 workers. We separate out the employment growth due to new startups into groupings with 1-5, 6-20, 21-100, and 101+ workers in their first year of observation. Panel A again considers average firm size, while Panel $\mathrm{B}$ uses the HHI concentration measure. These estimations only include region FEs, and the appendix reports similar patterns when industry FEs are also modelled.

A clear pattern exists across the entry size distribution. Larger average establishment size and greater industrial concentration retard entrepreneurship the most among the smallest firms. For example, a $10 \%$ increase in mean establishment size is associated with a $12 \%$ reduction in new employment growth due to startups with five workers or fewer. The same increase in average establishment size is associated, however, with a $1 \%$ reduction in new employment growth due to entering firms with more than 100 employees. The patterns across the columns show steady declines in elasticities as the size of new establishments increases. The impact for new firms with 6-20 workers is only slightly smaller than the impact for the smallest firms, while the elasticity for entrants with 21-100 employees is 50\% smaller. Larger establishments and greater concentration are associated with a decrease in the number of smaller startups, but not a decrease in the number of larger startups.

\footnotetext{
${ }^{4}$ We have separately confirmed that none of the results for new startups reported in this paper depend upon the construction sector, where startups are over-represented in Table 1.
} 


\section{Theoretical Model}

This section presents a formal treatment of entrepreneurship and industrial concentration. We explore a range of different explanations for the empirical observation that startup activity has a strong negative correlation with the size of existing firms. Our goal is to produce additional testable implications of these explanations.

We develop a simple model based on monopolistic competition following the classic approach of Dixit and Stiglitz (1977). Entrepreneurs create firms that earn profits by selling imperfectly substitutable goods that are produced with increasing returns to scale. The startup costs of entrepreneurship are financed through perfectly competitive capital markets, and no contractual frictions prevent firms from pledging their future profits to financiers.

Each company operates over an infinite horizon and faces a constant risk of being driven out of business by an exogenous shock, such as obsolescence of its product or the death of an entrepreneur whose individual skills are indispensable for the operation of the firm. These simple dynamics generate a stationary equilibrium, so that we can focus on the number and size of firms and on the level of entrepreneurial activity in the steady state.

The baseline model enables us to look at the role of amenities, fixed costs, and profitability in explaining firm creation. Several of its empirical predictions are very general: for instance, essentially any model would predict that an exogenous increase in profitability should result in an endogenous increase in activity. An advantage of our approach is that different elements can easily be considered within a single standard framework. We also extend the model to address multiple human capital levels and to allow for vertical integration.

\subsection{Baseline Model}

Consider a closed economy with a perfectly inelastic factor supply. There are $I$ cities characterized by their exogenous endowments of real estate $K_{i}$ and by their amenity levels $a_{i}$ such that $a_{i}>a_{i+1}$ for all $i$. There is a continuum of industries $g \in[0, G]$, each of which produces a continuum of differentiated varieties.

Consumers have identical homothetic preferences defined over the amenities $a$ of their city of residence, the amount of real estate $K$ that they consume for housing, and their consumption $q_{g}(\nu)$ of each variety in each industry. Specifically, we assume constant elasticity of substitution $\sigma(g)>1$ across varieties in each sector and an overall Cobb-Douglas utility function

$$
U=\log a+\rho \log K+(1-\rho) \int_{0}^{G} \beta(g) \log \left[\int_{0}^{n(g)} q_{g}(\nu)^{\frac{\sigma(g)-1}{\sigma(g)}} d \nu\right]^{\frac{\sigma(g)}{\sigma(g)-1}} d g
$$

with budget shares for consumption expenditures $\rho \in[0,1)$ and $\beta(g)>0$ such that $\int_{0}^{G} \beta(g) d g=$ 1. $n(g)$ denotes the equilibrium number of firms in each industry. 
Commodities are costlessly tradable across cities, while real estate is immobile. We assume for simplicity that real estate is owned by developers who reside in the same city where their property is located. $^{5}$ The economy comprises measure $L$ of workers who are perfectly mobile across space: each supplies inelastically one unit of labor. Letting $r_{i}$ denote the price of real estate and $w_{i}$ the wage in city $i$, spatial equilibrium for workers requires that

$$
\log a_{i}+\log w_{i}-\rho \log r_{i}=\log a_{j}+\log w_{j}-\rho \log r_{j} \text { for all } i, j:
$$

naturally, cities with higher amenities $\left(a_{i}>a_{i+1}\right)$ have compensatingly lower wages $\left(w_{i}<w_{i+1}\right)$ and higher rents $\left(r_{i}>r_{i+1}\right)$.

Within each industry, omitting for the sake of brevity the index $g$, the preferences described by equation 1 imply the sectoral price index

$$
P=\left[\int_{0}^{n} p(\nu)^{1-\sigma} d \nu\right]^{\frac{1}{1-\sigma}}
$$

and the demand function for each variety

$$
q(\nu)=R P^{\sigma-1} p(\nu)^{-\sigma},
$$

where $R=P Q$ is aggregate revenue in the sector, equal to a fraction $(1-\rho) \beta$ of total income.

Each variety $\nu$ is produced by a monopolistically competitive firm having increasing returns to scale. The cost function for a firm locating in city $i$ is

$$
c(q)=(f+q) r_{i}^{\kappa} w_{i}^{\lambda}
$$

This specification reflects a constant unit cost and an overhead requirement $f>0$ that measures the extent of economies of scale. Technology is Cobb-Douglas, with cost shares $\kappa>0$ for real estate and $\lambda>0$ for labor such that $\kappa+\lambda=1$. Monopolistic competition leads firms to adopt a constant mark-up over variable cost, so each product has price

$$
p=\frac{\sigma}{\sigma-1} r_{i}^{\kappa} w_{i}^{\lambda}
$$

Firms are created by entrepreneurs at a cost

$$
C=F r_{i}^{\kappa_{e}} w_{i}^{\lambda_{e}}
$$

again resulting from Cobb-Douglas technology with cost shares $\kappa_{e}+\lambda_{e}=1$. We assume that the cost shares of the two factors are different in the startup stage and in the operation of an established firm. In particular, we make the following assumption that ensures an equilibrium sorting of firms into cities, as shown in the appendix.

\footnotetext{
${ }^{5}$ Alternatively, we could allow for absentee ownership, and we would have rentiers living in extremely highamenity cities where no production takes place.
} 
Assumpition 1 Innovation is more labor intensive than production $\left(\lambda_{e}>\lambda\right)$.

Relocating a firm is prohibitively costly, so its location is chosen once and for all at the moment of its creation; this rules out the presence of "nursery cities" à la Duranton and Puga (2001). Each firm is forced out of the market in any period with a constant hazard rate $\delta \in(0,1)$. This risk implies that the stream of profits of a firm must be discounted by a constant factor to compute its present value. Thus we can assume for simplicity that the pure rate of time preference is nil, without qualitatively affecting the results.

In a steady-state equilibrium, all firms in the same sector generically choose to locate in the same city, as we show in the appendix. Thus the sectoral price index is

$$
P=n^{-\frac{1}{\sigma-1}} \frac{\sigma}{\sigma-1} r_{i}^{\kappa} w_{i}^{\lambda},
$$

and each firm earns profits

$$
\pi=\frac{R}{\sigma n}-f r_{i}^{\kappa} w_{i}^{\lambda} .
$$

Free entry implies that this equals the cost of entrepreneurship, which pins down the number of firms

$$
n=\frac{R}{\sigma\left(\delta F r_{i}^{\kappa_{e}} w_{i}^{\lambda_{e}}+f r_{i}^{\kappa} w_{i}^{\lambda}\right)} .
$$

In each period and for each sector the aggregate profits of existing firms coincide with the aggregate payments to factors employed by entrepreneurs to create new varieties in the same industry.

Firm size measured by labor employment equals

$$
\bar{L}=\lambda\left[\sigma f\left(\frac{r_{i}}{w_{i}}\right)^{\kappa}+(\sigma-1) \delta F\left(\frac{r_{i}}{w_{i}}\right)^{\kappa_{e}}\right],
$$

and sales revenues per worker equal

$$
\frac{\bar{R}}{\bar{L}}=\frac{\sigma\left[f\left(\frac{r_{i}}{w_{i}}\right)^{\kappa}+\delta F\left(\frac{r_{i}}{w_{i}}\right)^{\kappa_{e}}\right] w_{i}}{\lambda\left[\sigma f\left(\frac{r_{i}}{w_{i}}\right)^{\kappa}+(\sigma-1) \delta F\left(\frac{r_{i}}{w_{i}}\right)^{\kappa_{e}}\right]} .
$$

The fraction of workers in the sector employed by entrepreneurs creating new firms is

$$
\iota=\left\{1+\frac{\lambda}{\lambda_{e}}\left[\sigma \frac{f}{\delta F}\left(\frac{r_{i}}{w_{i}}\right)^{\lambda_{e}-\lambda}+\sigma-1\right]\right\}^{-1},
$$

which can also be expressed as

$$
\iota=\left[1+\frac{\bar{L}}{\lambda_{e} \delta F}\left(\frac{w_{i}}{r_{i}}\right)^{\kappa}\right]^{-1} .
$$


This condition delivers the amount of entrepreneurship in each industry. Inspection of the condition yields two possible explanations for the connection between the number of firms and the level of entrepreneurship. Relative employment in startups and the scale of existing firms move in opposite directions due to cross-sectoral variations in economies of scale and in product differentiation. We consider both in turn; proofs are provided in the appendix.

Proposition 1 Suppose that industries differ by the degree of economies of scale $f(g)$.

Within cities, sectors with higher economies of scale have fewer firms ( $\partial n / \partial f<0)$, higher average employment per established firm $(\partial \bar{L} / \partial f>0)$, lower average revenues per worker $(\partial(\bar{R} / \bar{L}) / \partial f<0)$, and a lower fraction of the work force employed by entrepreneurial startups $(\partial \iota / \partial f<0)$.

Across cities, sectors with higher economies of scale sort into cities with lower amenities, higher wages, and a lower cost of real estate.

This proposition explains the concentration of small firms, and the negative correlation between the size of existing firms and the amount of entrepreneurship, on the basis of cost differences across sectors. In particular, the focus is on variations in the overhead input requirement.

It is natural that sectors with higher economies of scale should have fewer, larger firms in equilibrium. Their sales per worker are lower because the labor input requirement per unit of output is the same in all industries, but those with a higher overhead additionally need more workers to defray their fixed costs. While in equilibrium the presence of fewer firms implies higher revenues per firm, this does not suffice to offset the direct decline in sales per worker as long as there is a positive cost of entrepreneurship.

The first part of the proposition highlights that sectors with higher fixed costs have not only a smaller number of firms but also a lower level of entrepreneurship. As the costs of operating a firm rise, the equilibrium number of firms unsurprisingly declines, and there is an accompanying decrease in the amount of entrepreneurial activity. As the cost of opening a new establishment rises, fewer people are interested in starting such establishments. The decrease in the steadystate number of firms entails a corresponding decline in the steady-state number of entrepreneurs, and thus of their employees. An increase in the overhead cost induces a less than proportional reduction in the equilibrium number of firms: thus the number of workers employed in managing existing firms increases.

This leads directly to the second part of the proposition. The spatial sorting of sectors is driven by relative factor intensities, since factor rewards move in opposite directions across cities. For sectors with higher economies of scale, the overall factor intensity is determined more by that of the overhead, and less by that of entrepreneurship. Innovation being the more laborintensive activity, sectors with lower firm scale and greater innovation are consequently attracted to high-amenity locations.

In addition or in alternative to supply-side differences, demand-side variation can also explain why entrepreneurship and small firms thrive in the same sectors. 
Proposition 2 Suppose that industries differ by the degree of product substitutability $\sigma(g)$ and therefore by the mark-up $\sigma(g) /[\sigma(g)-1]$.

Within cities, sectors with higher product substitutability and lower mark-ups have fewer firms $(\partial n / \partial \sigma<0)$, higher average employment per established firm $(\partial \bar{L} / \partial \sigma>0)$, lower average revenues per worker $(\partial(\bar{R} / \bar{L}) / \partial f<0)$, and a lower fraction of the work force employed by entrepreneurial startups $(\partial \iota / \partial \sigma<0)$.

Across cities, sectors with higher product substitutability and lower mark-ups sort into cities with lower amenities, higher wages, and a lower cost of real estate.

The degree of product substitutability is the primary determinant of price markups and profit levels in this model. With CES preferences, the level of competitiveness in each sector is entirely determined by the degree of product differentiation. If varieties are highly substitutable, competition is intense and mark-ups are low.

The decline in mark-ups and profitability makes the sector less attractive to entrepreneurs, so fewer firms enter the market. At the same time, each firm must operate on high volumes and low margins to defray its fixed costs. Again, in a stationary equilibrium fewer firms mean fewer startups and lower employment in innovation. On the other hand, a decrease in mark-ups entails an inversely proportional increase in employment in direct production activities. Hence entrepreneurship accounts for a lower share of employment.

The increase in the number of production workers also leads to lower sales per worker: the variable labor input per unit of revenue is the inverse of the mark-up. As the latter declines, so does the ratio of revenues to the total workforce, even if the overhead labor requirement is constant while revenues per firm rise as a consequence of the smaller equilibrium number of firms.

Lower product differentiation, which leads to lower profitability, implies that average factor intensity depends mostly on production costs. Since these constitute the least labor-intensive cost component, it follows that industries with harsher competitive conditions are particularly keen on inexpensive real estate, and thus locate in cities with lower amenities.

Thus we have shown how the connection between firm size and entrepreneurial activity can arise from exogenous variations in the underlying parameters that characterize supply and demand at the industry level. The same parameters can explain sorting of sectors into cities because of the fundamental difference between mobile labor and immovable real estate.

\subsection{Heterogeneous Human Capital}

The model can be extended to consider human capital as another determinant of entrepreneurship. Suppose that the economy is endowed with measure $L$ of unskilled workers and $H$ of skilled workers, and that technology is Cobb-Douglas in the two kinds of labor and real estate. Since both types of workers are perfectly mobile, the spatial equilibrium condition (eq. 2) implies that 
there is a single skill premium in the entire economy. Letting $w_{i}$ denote the wage of unskilled workers in city $i$, the wage of skilled workers is $h w_{i}$.

The cost function for a producer can be rewritten

$$
c(q)=(f+q) r_{i}^{\kappa} w_{i}^{\lambda+\eta} h^{\eta}
$$

with cost shares $\kappa+\lambda+\eta=1$; while for an entrepreneur the startup cost becomes

$$
C=F r_{i}^{\kappa_{e}} w_{i}^{\lambda_{e}+\eta_{e}} h^{\eta_{e}}
$$

with cost shares $\kappa_{e}+\lambda_{e}+\eta_{e}=1$. In equilibrium, the ratio of skilled to unskilled workers in each industry is determined by the skill intensity of each cost component and by their relative importance in the sector. In particular, we assume that innovation is not only the most laborintensive, but also the most skill-intensive activity.

Assumpition 2 Skill intensity is ranked so that $\eta_{e} / \lambda_{e}>\eta / \lambda$.

We can then establish the following result.

Proposition 3 Let industries differ either by the degree of economies of scale $f(g)$ or by the degree of product substitutability $\sigma(g)$. Within cities, relatively more skilled workers are then employed in sectors with more firms, lower average employment per established firm, and a higher fraction of the work force employed by entrepreneurial startups $(\partial(H / L) / \partial f<0$ and $\partial(H / L) / \partial \sigma<0)$.

The proposition formalizes the intuition that entrepreneurship and entrepreneurs go together. Since entrepreneurship is disproportionately reliant on human capital, the same industry characteristics that increase entrepreneurship and reduce firm size also increase the overall skill intensity of the sector and lead it to employ a higher share of skilled workers in equilibrium.

In this model, mobility is endogenous, and workers are always in a spatial equilibrium. As such, there is no way for endowments of human capital to lead to more entrepreneurship. To address this type of exogenous sorting, we would need to drop the spatial equilibrium assumption and assume that workers were either fixed or tied to an area by historical accident.

\subsection{Vertical Integration and the Chinitz Hypothesis}

A more significant extension of the model involves going beyond exogenous determinants of firm size and entrepreneurship to explain their negative correlation by an endogenous channel. In the spirit of Chinitz, we focus on the choice of firm organization. One of Chinitz's core ideas was that entrepreneurship would be higher in places that had abundant suppliers. In this model, we endogenize the decision to integrate suppliers and examine the implications of integration decisions on later entrepreneurship. 
In this structure, firms specialize in one stage of the production process and engage in outsourcing if they enter a market that already hosts a number of upstream and downstream firms that could become partners for the new entrepreneur. Alternatively, if existing producers are vertically integrated, newcomers will perceive a need to enter as an equally integrated firm. These considerations in turn affect the equilibrium level of entrepreneurship, and we show that they also account for a link between a multitude of smaller firms and higher rates of entry.

Formally, we follow Grossman and Helpman's (2002) model of integration versus outsourcing in industry equilibrium. The production process of each differentiated variety requires two stages of production that can be carried out within an integrated firm or by outsourcing. The operation of integrated firms is described by the baseline model above and yields profits

$$
\pi_{v}=\frac{1}{\sigma}\left(\frac{\sigma-1}{\sigma} \frac{P}{r_{i}^{\kappa} w_{i}^{\lambda}}\right)^{\sigma-1} R-f r_{i}^{\kappa} w_{i}^{\lambda} .
$$

Alternatively, firms may operate as specialized producers of final goods (overhead $f_{s}$ ) or intermediates (overhead $f_{m}$ ). The relationship between the two types of specialized producers is characterized by costly search and incomplete contracts.

After overhead costs are incurred, each firm must search for a partner. The probability of finding one is described by a matching function that has constant returns to scale. If there are $m$ and $s$ specialized intermediates and final goods producers in the market, respectively, the probability of a match is $\mu(\mathrm{s} / \mathrm{m})$ for each specialized intermediates producer and $\mu(\mathrm{s} / \mathrm{m}) \mathrm{m} / \mathrm{s}$ for each specialized final goods producer. The former match rate is increasing in the ratio $s / m$, while the latter is decreasing.

Once a match takes place, the two partners fully specialize to each other's technology. The intermediate goods supplier produces a quantity $q(\nu)$ of the specialized intermediate, and its unit input requirement is $\alpha$ times that of an integrated firm. After all costs have been sunk, the two partners bargain. The final goods producer can turn each unit of the specialized intermediate into one unit of the final good. Otherwise, both parties have an outside option of zero due to their complete specialization. The bargaining share of the producer of intermediates is $\omega$.

As a consequence, the price of each final good $\nu$ sold by specialized producers is

$$
p_{O}=\frac{\sigma}{\sigma-1} \frac{\alpha}{\omega} r^{\kappa} w^{\lambda} .
$$

Expected profits for each specialized intermediate goods producer are

$$
\pi_{m}=\mu\left(\frac{s}{m}\right) \frac{\omega}{\sigma}\left(\frac{\sigma-1}{\sigma} \frac{\omega}{\alpha} \frac{P}{r_{i}^{\kappa} w_{i}^{\lambda}}\right)^{\sigma-1} R-f_{m} r_{i}^{\kappa} w_{i}^{\lambda},
$$

and for each final goods producer

$$
\pi_{s}=\mu\left(\frac{s}{m}\right) \frac{m}{s}(1-\omega)\left(\frac{\sigma-1}{\sigma} \frac{\omega}{\alpha} \frac{P}{r_{i}^{\kappa} w_{i}^{\lambda}}\right)^{\sigma-1} R-f_{s} r_{i}^{\kappa} w_{i}^{\lambda} .
$$


Firms of all types are hit by a fatal shock with the same constant hazard rate $\delta$. The cost of entrepreneurship for a specialized producer of final goods is $F_{s}$ and for a specialized producer of intermediates is $F_{m}$. Free entry implies that

$$
\left\{\begin{array}{l}
\pi_{m} \leq \delta F_{m} r_{i}^{\kappa_{e}} w_{i}^{\lambda_{e}} \\
\pi_{s} \leq \delta F_{s} r_{i}^{\kappa_{e}} w_{i}^{\lambda_{e}}
\end{array}\right.
$$

which must hold with equality for specialization to be an equilibrium organizational form; and similarly

$$
\pi_{v} \leq \delta F r_{i}^{\kappa_{e}} w_{i}^{\lambda_{e}}
$$

which must hold with equality for integration to be an equilibrium organizational form. Generically, all firms in a sector prefer the same organizational form.

Since we are interested in the effect of organizational choice on entrepreneurship through channels other than the size of the overhead, which was already the focus of proposition 1 , we assume that

$$
\frac{f_{m}}{f}=\frac{F_{m}}{F}=\phi_{m}<1 \text { and } \frac{f_{s}}{f}=\frac{F_{s}}{F}=\phi_{s}<1 .
$$

In any equilibrium with specialization

$$
\frac{s}{m}=\sigma \frac{1-\omega}{\omega} \frac{\phi_{m}}{\phi_{s}}
$$

an equilibrium in which all producers are specialized exists if and only if

$$
\alpha^{\sigma-1} \phi_{m} \leq \omega^{\sigma} \mu\left(\sigma \frac{1-\omega}{\omega} \frac{\phi_{m}}{\phi_{s}}\right)
$$

On the other hand, an equilibrium in which all producers are integrated always exists, since a single specialized producer could never find a partner to operate profitably; however, it is stable if and only if the outsourcing equilibrium does not exist.

In the outsourcing equilibrium there are

$$
m=\frac{\omega R}{\sigma \phi_{m}\left(f r_{i}^{\kappa} w_{i}^{\lambda}+\delta F r_{i}^{\kappa_{e}} w_{i}^{\lambda_{e}}\right)}
$$

specialized producers of intermediates and

$$
s=\frac{(1-\omega) R}{\phi_{s}\left(f r_{i}^{\kappa} w_{i}^{\lambda}+\delta F r_{i}^{\kappa_{e}} w_{i}^{\lambda_{e}}\right)}
$$

specialized producers of final goods.

We can therefore prove the following result.

Proposition 4 Compared to an equilibrium in which all firms are vertically integrated, an equilibrium in which all firms are specialized producers (if it exists) has higher mark-ups, lower average employment per established firm, and a higher fraction of the work force employed by entrepreneurial startups. 
This proposition establishes that differences in the equilibrium organizational form across industries can account endogenously for the correlations that we previously explained exogenously.

The pervasive presence of specialized firms induces an increase in mark-ups as a direct consequence of incomplete contracting. Since production costs are incurred by a partner who will obtain only a fraction $\omega<1$ of revenues in ex-post bargaining, output is proportionally lower, and the mark-up is $1 / \omega$ times the one charged by an integrated firm. The reduction in the average size of each firm is also intuitive: outsourcing tends to increase the number of firms both by separating stages of production and by reducing fixed costs for each firm.

Most important, outsourcing also yields an increase in entrepreneurship, spurred by the opportunity of matching with a complementary specialized producer. Many entrepreneurs are employed in creating firms to enter the matching market. However, not all are matched in equilibrium, and the output of those that are is reduced by contracting frictions. This implies that the share of workers allocated to entry, as opposed to actual production, is higher than under vertical integration.

The equilibrium mode of organizational form is independent of location, since it is not a function of factor rewards. In fact, equilibrium selection is mostly determined by parameters specific to the integration decision. Outsourcing is obviously more likely when it involves greater cost reductions $\left(\phi_{m}, \phi_{s}\right.$, and $\alpha$ are low). Its likelihood is first increasing and then decreasing in $\omega$ on $(0,1)$, which is intuitive since both types of specialized producers must have incentives to enter the market in order for outsourcing to be sustainable.

The only parameter that affects both the properties of the baseline equilibrium with vertical integration and the likelihood of outsourcing is the elasticity of substitution $\sigma$. While its effect is not unambiguous, the following case is of particular interest.

Proposition 5 If $\log (\alpha / \omega)>1$ then outsourcing is more likely in sectors with a low elasticity of substitution $(\sigma)$ for any matching function $\mu($.$) having constant returns to scale.$

Changes in $\sigma$ have two opposite effects. On the one hand, greater substitutability reduces the number $m$ of firms that enter as specialized producers of intermediates and increases the probability that each of them successfully finds a match: this unambiguously favours outsourcing. On the other hand, for $\alpha>\omega$ outsourcing is so inefficient in the final stage of production that vertically integrated firms would charge lower prices: this tends to make them prevail when competition is tougher. For a sufficiently high value of the ratio $\alpha / \omega$, the latter effects is certain to dominate.

In this case, the results of proposition 2 are reinforced by the endogenous channel of firm organization. In particular, cities with higher amenity levels attract industries that are more likely to have an equilibrium with pervasive outsourcing, which are precisely the sectors that tend to have more numerous and smaller firms and a higher rate of entrepreneurship. 


\section{Origins of Entrepreneurial Clusters}

We turn now to empirical evidence on the origins of clusters of entrepreneurship. We first consider the explanation that there exist very high returns to entrepreneurship in certain regions and industries. We then examine cost factors. Finally, we present empirical evidence on the model's sorting predictions regarding amenities, human capital, and clusters of entrepreneurship. Throughout these exercises, we are assessing in part whether these forces can explain the small establishment size effect documented in Section 2.

\subsection{High Returns Rationales}

We first test whether returns to entrepreneurship and production are higher in places with smaller firms and abundant employment growth. Section 3's model characterizes this channel through the elasticity of substitution. Alternatively, the returns to entrepreneurship may be uniform spatially. This scenario would suggest that the strong correlation between initial industry structure and subsequent employment growth due to startups descends more from a reduction in the costs of entrepreneurship or supply side factors.

Table 4 presents evidence on these hypotheses. We calculate from the base Censuses (e.g., Census of Manufacturers, Census of Retail Trade) the 1997 dollar value of shipments per worker by region-industry separately for single-unit firms and multi-unit firms. We use this shipments per employee metric as a proxy for profitability, subject to including industry FEs that control for industry-level production techniques, and therefore the returns to entrepreneurship.

Columns 1 and 2 model log shipments per worker among single-unit firms as the dependent variable, while the last two columns consider the similar measure among multi-unit establishments. Column 1 does not find a strong relationship between average establishment size in 1992 of the region-industry and the value per worker subsequently evident in 1997. This weak explanatory power is both in economic magnitudes and in statistical significance. There is some evidence of greater initial employment in region-industries with high subsequent returns. This could be evidence for an agglomeration effect or just that there is more employment in places where the returns to that employment are higher.

The limited evidence for abnormal subsequent shipments per worker also extends in Column 2 to the industry concentration measure. Likewise, the third and fourth columns find even weaker relationships when instead considering the labor returns among establishments of multi-unit firms. The appendix repeats these estimations by sector. Very weak relationships are evident in all sectors including manufacturing, where the average establishment size effect is strongest in Figures $2 \mathrm{a}$ and $2 \mathrm{~b}$. These patterns suggest that abnormal returns are not the driving force behind the observed relationships. Instead, the results point us to theories that emphasize either an abundance of entrepreneurial types in the area or a reduction in the costs of entrepreneurship.

As a second test, Table 5 also verifies that the observed average size relationship is not 
due to product cycles and industry evolution. ${ }^{6}$ We calculate from the LBD the average age of establishments by region-industry with a cap at 15 years and older. The first column of Table 5 confirms that industry-regions with older establishments in 1992 have less entrepreneurship over the ensuing eight years. The second and third columns show, however, that this age regressor does little to explain the relationship between entry and initial average establishment size. The coefficients are very close to those reported in Table 2 , and the same holds for facility expansions in the latter three columns. Thus, while entrepreneurship is closely linked to region-industry evolution, this cannot explain the small establishment effect. ${ }^{7}$

\subsection{Lower Cost Rationales}

We next evaluate cost factors. Tables $6 \mathrm{~A}$ and $6 \mathrm{~B}$ first examine industrial structures in metropolitan areas for an indirect test. Table $6 \mathrm{~A}$ focuses on mean establishment size, while Table $6 \mathrm{~B}$ considers HHI concentration. In both tables, the first two columns consider startup entry, while the last two columns consider facility expansions. Our data include 273 cities and 66 SIC2 industries. We move to the SIC2 level when considering city-industry combinations to reduce the number of zero-valued observations. Even at the more aggregated industry level, however, not all city-industries are present, which results in 16,363 observations. The other details of the regressions remain as before.

Column 1 only includes industry FEs so that we can consider the correlation between employment growth due to startups and city-level characteristics. This regression shows that the large negative effect of greater average establishment size that is evident regionally is also evident by city-industry. A $10 \%$ increase in the mean 1992 establishment size of a city-industry is associated with an $8 \%$ reduction in employment growth due to startups over the ensuing eight years.

Returning to Chinitz's comparison of manufacturing in New York City and Pittsburgh, average establishment size is 0.37 log points higher in Pittsburgh than in New York in the LBD (45.9 employees versus 31.6). Our coefficient estimates suggest that this establishment size difference accounts for a -0.3 log point reduction in Pittsburgh's startup employment growth relative to New York in manufacturing. This small establishment effect represents a quarter of the difference in manufacturing entry between these two cities once population differences are accounted for.

We also find a sizable and statistically significant coefficient on the average establishment size in the city as a whole. Holding a local industry's own establishment size constant, entrepreneurship increases when the surrounding city has greater numbers of small establishments. The coefficients on initial employments are large and of similar magnitude to the mean establishment

\footnotetext{
${ }^{6}$ For example, Faberman (2007), Jovanovic and MacDonald (1994), and Klepper and Graddy (1990).

${ }^{7}$ Unreported estimations further disaggregate the average age effect. The negative effect for startup entry is particularly concentrated in the presence of many establishments of greater than ten years in age.
} 
size, but with opposite signs. This pattern suggests that the employment growth of new startups is quite closely correlated to the number of existing establishments in the area. Column 2 includes city FEs. In this case, the coefficient on average establishment size falls to -0.67, and growth is not quite one-for-one with existing employment in the conditional estimation.

Columns 3 and 4 look at expansions of existing businesses. The impact of average establishment size in the city-industry remains robustly negative but is smaller than for startups. The role of initial employment in the city-industry is also quite similar to the first two columns. The biggest change is that the city-level mean establishment size has a weakly positive impact on employment growth. These patterns support the view that small, decentralized suppliers and customers are more helpful or important for new startups than for expansions of established firms. In a related study, Glaeser and Kerr (2009) reach a similar conclusion when exploiting more direct inter-industry linkages within the manufacturing sector.

As a second and more direct approach, Table 7 examines the relationship between labor intensity and entrepreneurship rates. The model suggests a connection between higher labor intensity, lower fixed costs, and more entrepreneurship. Indeed, we believe that labor intensity is a reasonable proxy for lower overhead costs of running a firm, which should make entrepreneurship easier. ${ }^{8}$ Panel B of Table 7 shows that labor intensity at the region-industry level strongly predicts subsequent entry among startups, which supports that prediction of the model. However, controlling for labor intensity does not substantially diminish the average establishment size effect. Thus, while entry costs are clearly important, the relationship between initial industry structure and subsequent entrepreneurship is not due to differing factor intensities.

\subsection{Sort Rationales: Amenities}

The model featured one fundamental city-level attribute - the level of amenities. Better amenities drive up the price of land, attracting low fixed cost industries that tend to have higher levels of entrepreneurship. We start with these implications of the model and then ask whether amenity variables, or any others, can explain the strong connection between average establishment size and new establishment formation. While there are certainly many man-made local amenities, we focus on predetermined climate amenities that can be taken as exogenous. We collect city-level data on coastal access, January temperature, July temperature, snowfall, and precipitation. While all of these variables can impact both production and consumption, they seem likely to primarily impact consumer well-being rather than the efficiency of firms. ${ }^{9}$

We consolidate these variables into a single amenity index by using a housing price hedonic regression that is reported in the appendix. We regress the log average housing price in the metropolitan area in 1990 on these climate variables. Our primary specification uses just the log

\footnotetext{
${ }^{8}$ The results of proposition 1 would be unchanged if we assumed formally that the overhead is less labor intensive than the unit input coefficient.

${ }^{9}$ See Carlino and Saiz (2007), Chen and Rosenthal (2008), Gabriel and Rosenthal (2004), Glaeser et al. (2001), and Rosenthal and Ross (this issue).
} 
of each explanatory variable, and we have confirmed that we deliver very similar results using a piecewise linear function that is also reported in the appendix. The explanatory power of the two specifications are quite similar. The San Francisco Bay Area and Los Angeles are typically found to have the nicest consolidated amenities, while Little Rock, AR, and Tulsa, OK, are judged to have the weakest amenities.

A number of studies consider the productivity benefits that natural advantages can offer. ${ }^{10}$ The appendix also documents how this amenities index is mostly uncorrelated or negatively correlated with productive natural advantages like the cost of electricity or coal, the availability of farmland, and the availability of timberland across states. This suggests that our constructed amenities index is unlikely to be reflecting production-related benefits to entrepreneurship.

Following the model, we look at the interaction between amenities and the degree of labor intensity in the industry. Labor intensity is defined as the ratio between total payroll of the establishment and total shipments. In the model, this variable also captured the degree to which the industry was dependent on real estate or other inputs that become more expensive in high amenity places. As such, the model predicted that labor intensive industries would particularly locate in high amenity areas.

Table 8 examines the relationship between this amenity index and both employment and entrepreneurship. The first two regressions consider industrial specialization across cities. Column 1 regresses log total employment by city-industry on the city's amenity index, the industry's labor intensity, and their interaction. Variables are demeaned prior to interaction to restore main effects. There is a strong positive correlation between the amenity index and the overall level of employment in the metropolitan area. High amenity places generally attract people and firms. Labor intensive industries are also generally larger in size. The interaction of amenities and labor intensity is strongly positive, implying that more labor intensive industries are disproportionately located in high amenity cities. The model's predicted pattern of industrial specialization is thus generally supported and persists in Column 2's conditional estimations.

Columns 3 to 5 consider employment growth due to startup entry as the outcome measure. The coefficient on city-level amenities remains positive and quite significant, even after controlling for initial employment in the city-industry. When we do not control for initial employment, the coefficient on the amenity index more than doubles in size. This simple association likely captures elements of regional growth and entrepreneurship in nice places. A related literature also considers how higher home prices can encourage entrepreneurship by easing liquidity constraints. $^{11}$

While the raw effect of amenities is quite positive, we do not find that the interaction works in the expected direction. There is a weak negative relationship between the interaction and employment growth due to startups. As would be expected, this negative effect flips sign when

\footnotetext{
${ }^{10}$ See Ellison and Glaeser (1999), Ellison et al. (2009), Glaeser and Kerr (2009), Holmes and Lee (2009), and Rosenthal and Strange (2001).

${ }^{11}$ For example, Black et al. (1996), Evans and Jovanovic (1989), Hurst and Lusardi (2004), and Nanda (2009).
} 
we do not control for initial employment in the city-industry. The interaction becomes smaller in magnitude and statistically insignificant in the fourth regression that includes city and industry FEs. Thus, while the spatial sorting follows the model's predictions, there does not appear to be an additional premium for entrepreneurship.

Column 5 further includes average establishment size as a control in the specification with industry and city FEs. The conditional framework does little to change the estimated interaction effect, but the interaction also does little to diminish the establishment size effect. The measured elasticity is essentially identical to that estimated in Table 6A. As a result, we conclude that the small establishment size effect extends beyond the sorting of labor intensive industries into high amenity areas.

Columns 6 and 7 examine the connection between amenities and employment growth due to entry of establishments that are part of existing firms. The raw effect of amenities in this regression is still positive, although it is small. The small coefficient on amenities reflects the fact that we are controlling for initial employment. Without that control, the amenity measure has a large coefficient of 0.8 . In this case, the interaction is positive but statistically insignificant. In the seventh regression, we include city and industry FEs and the interaction again is positive. The last column includes log of average establishment size in the city industry as a control. Again, the control does little to our estimated coefficients, and the control remains similar in magnitude to that estimated in Table $6 \mathrm{~A}$. The establishment size effect is not due to the industrial sorting considered here.

Table 8 shows a robust relationship between the amenity index and both employment and employment growth. It is also true that the amenity index has a greater effect on employment levels in labor intensive industries. However, amenities do not have a significantly greater impact on growth for more labor intensive industries. There is a slight positive interaction effect for facility expansions and a slight negative effect for startups.

\subsection{Sort Rationales: Human Capital}

In the model, amenities are an exogenous force that shifts the supply of entrepreneurs across space. We now look at the share of the city's population with college degrees. The spatial human capital distribution in the model is endogenously determined through sorting, yet there is certainly abundant evidence suggesting that education patterns are quite permanent across places. Treating the distribution of educated workers as exogenous is a natural half-way point towards treating the supply of entrepreneurs as an outside force. If the educated share of the population in a city is reasonably fixed, and if educated workers are particularly intensively used in entrepreneurship especially in high human capital industries, then this supply of entrepreneurs could also explain the establishment size effect. ${ }^{12}$

\footnotetext{
${ }^{12}$ Carlino and Hunt (2007), for example, emphasize the role of local human capital in explaining the geography of invention. See also Buenstorf and Klepper (2007), Doms et al. (this issue), and Marx et al. (2007).
} 
In the first two regressions of Table 9, we examine again industry employment. We include both the amenity index and the share of the city's population with college degrees as control variables. The coefficient on the amenity index falls significantly when we control for education levels, perhaps reflecting that amenities increase employment in part by attracting more educated people. We also find that there is a positive interaction between both variables and the education intensity of the industry, as measured by the share of the industry's workforce with college degrees at the national level. Unsurprisingly, industries that depend upon college workers locate in cities with many college workers. Such industries also locate in cities rich with amenities. The second regression includes city and industry FEs and continues to find this industrial specialization.

The third and fourth regressions use the employment growth due to startups as the dependent variable. We control for initial employment and average establishment size. Column 3 finds that places with more educated workforces have more startup growth, especially in industries that depend upon college-educated workers. While educated workers are associated with entrepreneurship, this does not meaningfully explain the average establishment size effect. The fourth column includes industry and city FEs. Again, the interaction between city education levels and the college share in the industry remains significant, but there is little impact on the estimated establishment size effect.

In the last two regressions, we consider employment growth due to affiliated new establishments. In that case, we find a positive interaction between the college share of the industry and both city-level amenities and human capital for explaining entry. Industries dependent upon college workers are expanding in places with many educated workers and in places with good weather. However, once again this sorting does not explain the establishment size effect.

\section{Conclusion}

The connection between small average establishment size and subsequent employment growth through startups is remarkably robust. It is strongest for manufacturing but present to some degree for startups in all sectors. This effect does not reflect industrial sorting on its own nor city-level omitted variables. Moreover, it is confirmed by the complementary study of Rosenthal and Strange (2009). However, we remain unsure about whether this correlation represents some causal link between small establishment size and entry or whether it reflects omitted variables that explain both outcomes.

The evidence on shipments per worker suggests that the returns to production are probably comparable, rather than higher, in city-industries with lots of small establishments. This fact pushes us away from theories that emphasize abnormal returns to production and towards theories that emphasize lower costs of entrepreneurship or greater supplies of entrepreneurs. We likewise confirm that the small establishment effect is not due to industry evolution, product cycles, and mean establishment age, although each of these is individually important for explaining 
entry.

There is evidence that supports the view that entrepreneurship is more common when its costs are lower. For example, the connection between labor intensity and entrepreneurship suggests that large fixed costs deter entrepreneurship. Entrepreneurship is also higher when suppliers are independent (see also Glaeser and Kerr, 2009). Yet, these factors explain little of the connection between entrepreneurship and small establishment size.

We are left with two explanations for the connection between small establishments and subsequent firm births: lower fixed costs and a greater supply of entrepreneurs. Our variables capturing lower fixed costs, after all, may only capture a tiny amount of true cost differentials across space. This would lead us to underestimate its importance. Alternatively, Chinitz's argument that some places just have a greater supply of entrepreneurs may hold.

Yet theories that emphasize the supply of entrepreneurs face both empirical and theoretical challenges. The theoretical challenge, which is the less onerous one, is to craft models where entrepreneurs are formed by some local variable and face limited mobility. While neither feature is standard in spatial models, it is relatively straightforward to imagine ways of perturbing those models to incorporate those features that would not break with the core traditions of spatial economics.

The empirical challenge is harder. To show the importance of the supply of entrepreneurship, there must be well-measured exogenous variables that capture and drive entrepreneurship supply. Certainly, our work illustrates that using broad-brush measures like overall education levels is likely to be insufficient. Yet, despite the difficulties of this challenge, we suspect that there is truth to Chinitz's hypothesis and that at least some of the connection between small firms and subsequent employment growth reflects heterogeneity in the supply of entrepreneurs. 


\section{A Appendix}

\section{A.1 Equilibrium Sorting}

In equilibrium, the expected value of entrepreneurship in sector $g$ (whose mention we omit for the sake of brevity) in city $i$ is

$$
V_{i}=\frac{1}{\delta}\left[\frac{(\sigma-1)^{\sigma-1}}{\sigma^{\sigma}} R P^{\sigma-1}\left(r_{i}^{\kappa} w_{i}^{\lambda}\right)^{1-\sigma}-f r_{i}^{\kappa} w_{i}^{\lambda}\right]-F r_{i}^{\kappa_{e}} w_{i}^{\lambda_{e}} .
$$

If $n_{i} \geq 0$ firms are located in each city $i$, then

$$
P=\frac{\sigma}{\sigma-1}\left[\sum_{i=1}^{I} n_{i}\left(r_{i}^{\kappa} w_{i}^{\lambda}\right)^{1-\sigma}\right]^{\frac{1}{1-\sigma}}
$$

and

$$
V_{i}=\frac{1}{\delta}\left[\frac{R}{\sigma} \frac{\left(r_{i}^{\kappa} w_{i}^{\lambda}\right)^{1-\sigma}}{\sum_{j=1}^{I} n_{j}\left(r_{j}^{\kappa} w_{j}^{\lambda}\right)^{1-\sigma}}-f r_{i}^{\kappa} w_{i}^{\lambda}\right]-F r_{i}^{\kappa_{e}} w_{i}^{\lambda_{e}} .
$$

Free entry implies that $V_{i} \leq 0$ and $n_{i} \geq 0$ for all $i$ with complementary slackness, namely that

$$
\left(f r_{i}^{\kappa} w_{i}^{\lambda}+\delta F r_{i}^{\kappa_{e}} w_{i}^{\lambda_{e}}\right)\left(r_{i}^{\kappa} w_{i}^{\lambda}\right)^{\sigma-1} \geq \frac{R}{\sigma} \frac{1}{\sum_{j=1}^{I} n_{j}\left(r_{j}^{\kappa} w_{j}^{\lambda}\right)^{1-\sigma}} \text { and } n_{i} \geq 0 \text { for all } i
$$

with complementary slackness.

This condition has the intuitive consequence that in equilibrium a city can only have more expensive real estate if it has a lower wage, or else it would not be rational for any industry to locate there. Thus we can order cities so that $w_{i}<w_{i+1}$ and $r_{i}>r_{i+1}$. The spatial-indifference condition for individuals (eq. 2) implies that this is the ordering of locations by decreasing amenity, $a_{i}>a_{i+1}$.

If sectors can also be ordered by increasing economies of scale $\left(f^{\prime}(g)>0\right)$ or increasing product substitutability $\left(\sigma^{\prime}(g)>0\right)$, then in equilibrium they correspondingly sort into cities provided that some conditions on the relative factor intensity of different cost components are satisfied.

Lemma 1 Suppose that industries differ by the degree of economies of scale $f(g)$. Consider two cities $i$ and $j$ such that $r_{i}<r_{j}$ and $w_{i}>w_{j}$. If firms in sector $\bar{g}$ are located in city $i$, then no firms in sectors with higher economies of scale than $\bar{g}$ locate in city $j\left(f(g)>f(\bar{g}) \Rightarrow n_{j}(g)=0\right)$. If firms in sector $\bar{g}$ are located in city $j$, then no firms in sectors with lower economies of scale than $\bar{g}$ locate in city $i\left(f(g)<f(\bar{g}) \Rightarrow n_{i}(g)=0\right)$.

Proof. The equilibrium condition implies that

$$
n_{i}(g)>0 \Rightarrow \frac{f(g) r_{i}^{\kappa-\kappa_{e}}+\delta F w_{i}^{\lambda_{e}-\lambda}}{f(g) r_{j}^{\kappa-\kappa_{e}}+\delta F w_{j}^{\lambda_{e}-\lambda}} \leq\left(\frac{r_{j}}{r_{i}}\right)^{\kappa_{e}+(\sigma-1) \kappa}\left(\frac{w_{j}}{w_{i}}\right)^{\lambda \sigma},
$$




$$
n_{j}(g)>0 \Rightarrow \frac{f(g) r_{i}^{\kappa-\kappa_{e}}+\delta F w_{i}^{\lambda_{e}-\lambda}}{f(g) r_{j}^{\kappa-\kappa_{e}}+\delta F w_{j}^{\lambda_{e}-\lambda}} \geq\left(\frac{r_{j}}{r_{i}}\right)^{\kappa_{e}+(\sigma-1) \kappa}\left(\frac{w_{j}}{w_{i}}\right)^{\lambda \sigma},
$$

and that

$$
\begin{aligned}
& \frac{f(g) r_{i}^{\kappa-\kappa_{e}}+\delta F w_{i}^{\lambda_{e}-\lambda}}{f(g) r_{j}^{\kappa-\kappa_{e}}+\delta F w_{j}^{\lambda_{e}-\lambda}}<\left(\frac{r_{j}}{r_{i}}\right)^{\kappa_{e}+(\sigma-1) \kappa}\left(\frac{w_{j}}{w_{i}}\right)^{\lambda \sigma} \Rightarrow n_{j}(g)=0, \\
& \frac{f(g) r_{i}^{\kappa-\kappa_{e}}+\delta F w_{i}^{\lambda_{e}-\lambda}}{f(g) r_{j}^{\kappa-\kappa_{e}}+\delta F w_{j}^{\lambda_{e}-\lambda}}>\left(\frac{r_{j}}{r_{i}}\right)^{\kappa_{e}+(\sigma-1) \kappa}\left(\frac{w_{j}}{w_{i}}\right)^{\lambda \sigma} \Rightarrow n_{i}(g)=0 .
\end{aligned}
$$

For $r_{i}<r_{j}, w_{i}>w_{j}$ and $\kappa>\kappa_{e}$,

$$
\frac{\partial}{\partial f} \frac{f r_{i}^{\kappa-\kappa_{e}}+\delta F w_{i}^{\lambda_{e}-\lambda}}{f r_{j}^{\kappa-\kappa_{e}}+\delta F w_{j}^{\lambda_{e}-\lambda}}=\frac{\delta F\left(r_{i}^{\kappa-\kappa_{e}} w_{j}^{\lambda_{e}-\lambda}-r_{j}^{\kappa-\kappa_{e}} w_{i}^{\lambda_{e}-\lambda}\right)}{\left(f r_{j}^{\kappa-\kappa_{e}}+\delta F w_{j}^{\lambda_{e}-\lambda}\right)^{2}}<0 .
$$

Thus if $n_{i}(\bar{g})>0$ then $n_{j}(g)=0$ for all $g$ such that $f(g)>f(\bar{g})$ because for these sectors

$$
\frac{f(g) r_{i}^{\kappa-\kappa_{e}}+\delta F w_{i}^{\lambda_{e}-\lambda}}{f(g) r_{j}^{\kappa-\kappa_{e}}+\delta F w_{j}^{\lambda_{e}-\lambda}}<\frac{f(\bar{g}) r_{i}^{\kappa-\kappa_{e}}+\delta F w_{i}^{\lambda_{e}-\lambda}}{f(\bar{g}) r_{j}^{\kappa-\kappa_{e}}+\delta F w_{j}^{\lambda_{e}-\lambda}} \leq\left(\frac{r_{j}}{r_{i}}\right)^{\kappa_{e}+(\sigma-1) \kappa}\left(\frac{w_{j}}{w_{i}}\right)^{\lambda \sigma}
$$

and if $n_{j}(\bar{g})>0$ then $n_{i}(g)=0$ for all $g$ such that $f(g)<f(\bar{g})$ because for these sectors

$$
\frac{f(g) r_{i}^{\kappa-\kappa_{e}}+\delta F w_{i}^{\lambda_{e}-\lambda}}{f(g) r_{j}^{\kappa-\kappa_{e}}+\delta F w_{j}^{\lambda_{e}-\lambda}}>\frac{f(\bar{g}) r_{i}^{\kappa-\kappa_{e}}+\delta F w_{i}^{\lambda_{e}-\lambda}}{f(\bar{g}) r_{j}^{\kappa-\kappa_{e}}+\delta F w_{j}^{\lambda_{e}-\lambda}} \geq\left(\frac{r_{j}}{r_{i}}\right)^{\kappa_{e}+(\sigma-1) \kappa}\left(\frac{w_{j}}{w_{i}}\right)^{\lambda \sigma} .
$$

Lemma 2 Suppose that industries differ by the degree of product substitutability $\sigma(g)$. Consider two cities $i$ and $j$ such that $r_{i}<r_{j}$ and $w_{i}>w_{j}$. If firms in sector $\bar{g}$ are located in city $i$, then no firms in sectors with higher product substitutability than $\bar{g}$ locate in city $j(\sigma(g)>\sigma(\bar{g}) \Rightarrow$ $\left.n_{j}(g)=0\right)$. If firms in sector $\bar{g}$ are located in city $j$, then no firms in sectors with lower product substitutability than $\bar{g}$ locate in city $i\left(\sigma(g)<\sigma(\bar{g}) \Rightarrow n_{i}(g)=0\right)$.

Proof. The equilibrium condition implies that

$$
\begin{aligned}
& n_{i}(g)>0 \Rightarrow\left(\frac{r_{i}^{\kappa} w_{i}^{\lambda}}{r_{j}^{\kappa} w_{j}^{\lambda}}\right)^{\sigma(g)-1} \leq \frac{f r_{j}^{\kappa} w_{j}^{\lambda}+\delta F r_{j}^{\kappa_{e}} w_{j}^{\lambda_{e}}}{f r_{i}^{\kappa} w_{i}^{\lambda}+\delta F r_{i}^{\kappa_{e}} w_{i}^{\lambda_{e}}}, \\
& n_{j}(g)>0 \Rightarrow\left(\frac{r_{i}^{\kappa} w_{i}^{\lambda}}{r_{j}^{\kappa} w_{j}^{\lambda}}\right)^{\sigma(g)-1} \geq \frac{f r_{j}^{\kappa} w_{j}^{\lambda}+\delta F r_{j}^{\kappa_{e}} w_{j}^{\lambda_{e}}}{f r_{i}^{\kappa} w_{i}^{\lambda}+\delta F r_{i}^{\kappa_{e}} w_{i}^{\lambda_{e}}},
\end{aligned}
$$

and that

$$
\left(\frac{r_{i}^{\kappa} w_{i}^{\lambda}}{r_{j}^{\kappa} w_{j}^{\lambda}}\right)^{\sigma(g)-1}<\frac{f r_{j}^{\kappa} w_{j}^{\lambda}+\delta F r_{j}^{\kappa_{e}} w_{j}^{\lambda_{e}}}{f r_{i}^{\kappa} w_{i}^{\lambda}+\delta F r_{i}^{\kappa_{e}} w_{i}^{\lambda_{e}}} \Rightarrow n_{j}(g)=0
$$




$$
\left(\frac{r_{i}^{\kappa} w_{i}^{\lambda}}{r_{j}^{\kappa} w_{j}^{\lambda}}\right)^{\sigma(g)-1}>\frac{f r_{j}^{\kappa} w_{j}^{\lambda}+\delta F r_{j}^{\kappa_{e}} w_{j}^{\lambda_{e}}}{f r_{i}^{\kappa} w_{i}^{\lambda}+\delta F r_{i}^{\kappa_{e}} w_{i}^{\lambda_{e}}} \Rightarrow n_{i}(g)=0
$$

For $r_{i}<r_{j}$ and $\kappa>\kappa_{e}$,

$$
r_{i}^{\kappa} w_{i}^{\lambda} \geq r_{j}^{\kappa} w_{j}^{\lambda} \Rightarrow r_{i}^{\kappa_{e}} w_{i}^{\lambda_{e}}>r_{j}^{\kappa_{e}} w_{j}^{\lambda_{e}}
$$

and therefore

$$
n_{i}(g)>0 \Rightarrow r_{i}^{\kappa} w_{i}^{\lambda}<r_{j}^{\kappa} w_{j}^{\lambda} \Rightarrow \frac{\partial}{\partial \sigma}\left(\frac{r_{i}^{\kappa} w_{i}^{\lambda}}{r_{j}^{\kappa} w_{j}^{\lambda}}\right)^{\sigma-1}=\left(\frac{r_{i}^{\kappa} w_{i}^{\lambda}}{r_{j}^{\kappa} w_{j}^{\lambda}}\right)^{\sigma-1} \log \frac{r_{i}^{\kappa} w_{i}^{\lambda}}{r_{j}^{\kappa} w_{j}^{\lambda}}<0 .
$$

Thus if $n_{i}(\bar{g})>0$ then $n_{j}(g)=0$ for all $g$ such that $\sigma(g)>\sigma(\bar{g})$ because for these sectors

$$
\left(\frac{r_{i}^{\kappa} w_{i}^{\lambda}}{r_{j}^{\kappa} w_{j}^{\lambda}}\right)^{\sigma(g)-1}<\left(\frac{r_{i}^{\kappa} w_{i}^{\lambda}}{r_{j}^{\kappa} w_{j}^{\lambda}}\right)^{\sigma(\bar{g})-1} \leq \frac{f r_{j}^{\kappa} w_{j}^{\lambda}+\delta F r_{j}^{\kappa_{e}} w_{j}^{\lambda_{e}}}{f r_{i}^{\kappa} w_{i}^{\lambda}+\delta F r_{i}^{\kappa_{e}} w_{i}^{\lambda_{e}}}
$$

If $n_{j}(\bar{g})>0$, suppose that there exists a sector $\hat{g}$ such that $n_{i}(\hat{g})>0$ but $\sigma(\hat{g})<\sigma(\bar{g})$. The proof above then implies that $n_{j}(\bar{g})=0$, a contradiction. Thus if $n_{i}(\bar{g})>0$ then $n_{j}(g)=0$ for all $g$ such that $\sigma(g)<\sigma(\bar{g})$.

For any cities $i$ and $j$, there can be no more than one sector whose firms are located in both. For any cities $i, j$, and $k$ with $a_{i}>a_{j}>a_{k}$, there can be no sector whose firms are located in $i$ and $k$ but not in $j$, or else no sector would locate in $j$. Moreover, with a continuum of sectors, none can be located in more than two cities, or else one city would need to host only a single non-measurable sector, which would be insufficient to employ the city's endowment of immobile real estate.

Ordering cities so that $a_{i}>a_{i+1}$ and sectors so that $f^{\prime}(g)>0$ or $\sigma^{\prime}(g)>0$, these lemmas imply that in equilibrium firms in sectors $g \in\left[\bar{g}_{i-1}, \bar{g}_{i}\right]$ locate in city $i$, where $\bar{g}_{0}=0$ and $\bar{g}_{I}=G$, while the remaining $I-1$ thresholds $\bar{g}_{i}$ are endogenously determined. Generically, sectors are located in a single city, with at most a non-measurable set of $I-1$ industries having firms in two cities.

We can write the spatial equilibrium condition for firms as

$$
\frac{\left(r_{i}^{\kappa} w_{i}^{\lambda}\right)^{\sigma\left(\bar{g}_{i-1}\right)-1}\left[f\left(\bar{g}_{i-1}\right) r_{i}^{\kappa} w_{i}^{\lambda}+\delta F_{e} r_{i}^{\kappa_{e}} w_{i}^{\lambda_{e}}\right]}{\left(r_{i-1}^{\kappa} w_{i-1}^{\lambda}\right)^{\sigma\left(\bar{g}_{i-1}\right)-1}\left[f\left(\bar{g}_{i-1}\right) r_{i-1}^{\kappa} w_{i-1}^{\lambda}+\delta F_{e} r_{i-1}^{\kappa_{e}} w_{i-1}^{\lambda_{e}}\right]}=1 \text { for all } i>1,
$$

where it is understood that either $\sigma^{\prime}(g)>0$ and $f^{\prime}(g)=0$ or $\sigma^{\prime}(g)=0$ and $f^{\prime}(g)>0$.

For each city $i$ and each sector $g \in\left(\bar{g}_{i-1}, \bar{g}_{i}\right]$, aggregate factor payments satisfy

$$
\left\{\begin{array}{l}
r_{i} K(g)=\left[\kappa \sigma(g)-\frac{\kappa-\kappa_{e}}{1+\frac{f(g)}{\delta F}\left(\frac{r_{i}}{w_{i}}\right)^{\kappa-\kappa_{e}}}\right] \frac{(1-\rho) \beta(g) Y}{\sigma(g)} \\
w_{i} L(g)=\left[\lambda \sigma(g)+\frac{\lambda_{e}-\lambda}{1+\frac{f(g)}{\delta F}\left(\frac{r_{i}}{w_{i}}\right)^{\kappa-\kappa_{e}}}\right] \frac{(1-\rho) \beta(g) Y}{\sigma(g)}
\end{array},\right.
$$


and aggregate income

$$
Y=\sum_{i=1}^{I}\left[r_{i} K_{i}+w_{i} \int_{\bar{g}_{i-1}}^{\bar{g}_{i}} L(g) d g\right]
$$

can be normalized to unity.

Considering that a fraction $\rho$ of income in city $i$ is spent on final consumption of real estate in the same city, the full-employment condition for real estate is

$$
(1-\rho) r_{i} K_{i}=\int_{\bar{g}_{i-1}}^{\bar{g}_{i}}\left[r_{i} K(g)+\rho w_{i} L(g)\right] d g \text { for all } i,
$$

while that for labor is

$$
L=\int_{0}^{G} L(g) d g .
$$

Recalling the spatial equilibrium condition for workers (eq. 2), the equilibrium is characterized by a system of $3 I-1$ equations in as many unknowns: the $I-1$ cutoffs $\bar{g}_{i}$ and the $2 I$ factor rewards $\left(r_{i}, w_{i}\right)$ :

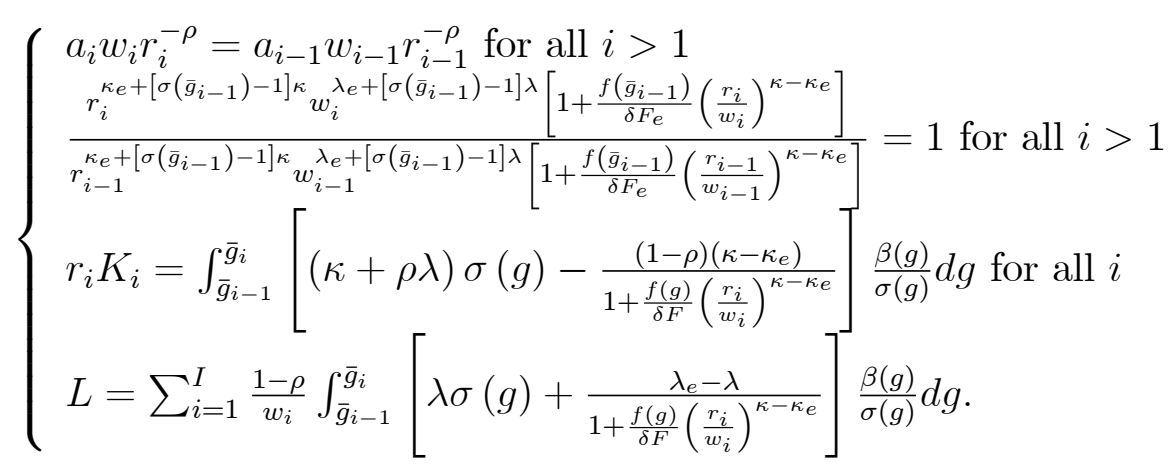

\section{A.2 Proof of Proposition 1}

The sorting of industries into cities has been proved by lemma 1, which also establishes that all firms in the same sector generically locate in the same city.

Sector $g$ located in city $i$ has the equilibrium number of firms given by equation 10, such that

$$
\frac{\partial n}{\partial f}=-\frac{R r_{i}^{\kappa} w_{i}^{\lambda}}{\sigma\left(\delta F r_{i}^{\kappa_{e}} w_{i}^{\lambda_{e}}+f r_{i}^{\kappa} w_{i}^{\lambda}\right)^{2}}<0 ;
$$

the average firm size measured by labor employment given by equation 11, such that

$$
\frac{\partial \bar{L}}{\partial f}=\lambda \sigma\left(\frac{r_{i}}{w_{i}}\right)^{\kappa}>0 ;
$$

the average revenue per worker given by equation 12 , such that

$$
\frac{\partial}{\partial f} \frac{\bar{R}}{\bar{L}}=\frac{-\delta \sigma F\left(\frac{r_{i}}{w_{i}}\right)^{\kappa+\kappa_{e}} w_{i}}{\lambda\left[\sigma f\left(\frac{r_{i}}{w_{i}}\right)^{\kappa}+(\sigma-1) \delta F\left(\frac{r_{i}}{w_{i}}\right)^{\kappa_{e}}\right]^{2}}<0 ;
$$


and the fraction of workers employed by entrepreneurs creating new firms given by equation 13 , such that

$$
\frac{\partial \iota}{\partial f}=-\iota^{2} \frac{\lambda}{\lambda_{e}} \sigma \frac{1}{\delta F}\left(\frac{r_{i}}{w_{i}}\right)^{\lambda_{e}-\lambda}<0 .
$$

\section{A.3 Proof of Proposition 2}

The sorting of industries into cities has been proved by lemma 2, which also establishes that all firms in the same sector generically locate in the same city.

Sector $g$ located in city $i$ has the equilibrium number of firms given by equation 10, such that

$$
\frac{\partial n}{\partial \sigma}=-\frac{R}{\sigma^{2}\left(\delta F r_{i}^{\kappa_{e}} w_{i}^{\lambda_{e}}+f r_{i}^{\kappa} w_{i}^{\lambda}\right)}<0 ;
$$

the average firm size measured by labor employment given by equation 11, such that

$$
\frac{\partial \bar{L}}{\partial \sigma}=\lambda\left[f\left(\frac{r_{i}}{w_{i}}\right)^{\kappa}+\delta F\left(\frac{r_{i}}{w_{i}}\right)^{\kappa_{e}}\right]>0 ;
$$

the average revenue per worker given by equation 12 , such that

$$
\frac{\partial}{\partial \sigma} \frac{\bar{R}}{\bar{L}}=\frac{-\delta\left[f\left(\frac{r_{i}}{w_{i}}\right)^{\kappa}+\delta F\left(\frac{r_{i}}{w_{i}}\right)^{\kappa_{e}}\right] F\left(\frac{r_{i}}{w_{i}}\right)^{\kappa_{e}} w_{i}}{\lambda\left[\sigma f\left(\frac{r_{i}}{w_{i}}\right)^{\kappa}+(\sigma-1) \delta F\left(\frac{r_{i}}{w_{i}}\right)^{\kappa_{e}}\right]^{2}}<0
$$

and the fraction of workers employed by entrepreneurs creating new firms given by equation 13 , such that

$$
\frac{\partial \iota}{\partial \sigma}=-\iota^{2} \frac{\lambda}{\lambda_{e}}\left[1+\frac{f}{\delta F}\left(\frac{r_{i}}{w_{i}}\right)^{\lambda_{e}-\lambda}\right]<0 .
$$

\section{A.4 Proof of Proposition 3}

The ratio of skilled to unskilled workers in each industry equals

$$
\frac{H}{L}=\frac{1}{h} \frac{\frac{\delta F r_{i}^{\kappa_{e}} w_{i}^{\lambda_{e}+\eta_{e}} h^{\eta_{e}}}{\frac{\delta F r_{i}^{\kappa e} w_{i}^{\lambda_{e}+\eta}{ }^{+} h^{\eta_{e}}+f r_{i}^{\kappa} w_{i}^{\lambda+\eta} h^{\eta}}{}}\left(\eta_{e}-\eta\right)+\eta \sigma}{\delta F r_{i}^{\kappa_{e}} w_{i}^{\lambda_{e}+\eta_{e}} h^{\eta_{e}}},
$$

which is decreasing in $f$ and in $\sigma$ if and only if $\eta_{e} / \lambda_{e}>\eta / \lambda$.

\section{A.5 Proof of Proposition 4}

In an equilibrium with pervasive outsourcing the mark-up over marginal cost is

$$
\frac{\sigma}{\sigma-1} \frac{1}{\omega}>\frac{\sigma}{\sigma-1}
$$


where the right-hand side is the mark-up in an equilibrium with pervasive integration. Firm size measured by labor employment equals

$$
\bar{L}_{O}=\frac{\lambda\left[\sigma f\left(\frac{r_{i}}{w_{i}}\right)^{\kappa}+(\sigma-1) \omega \delta F\left(\frac{r_{i}}{w_{i}}\right)^{\kappa_{e}}\right]}{\frac{\omega}{\phi_{m}}+\frac{\sigma(1-\omega)}{\phi_{s}}}<\bar{L}
$$

and the fraction of workers in the sector employed by entrepreneurs creating new firms is

$$
\iota_{O}=\left\{1+\frac{1}{\omega+\sigma(1-\omega)}\left[(\sigma-1) \omega+\sigma \frac{f}{\delta F}\left(\frac{r_{i}}{w_{i}}\right)^{\lambda_{e}-\lambda}\right] \frac{\lambda}{\lambda_{e}}\right\}^{-1}>\iota
$$

\section{A.6 Proof of Proposition 5}

The feasibility condition (eq. 25) implies that the likelihood of outsourcing is decreasing in $\sigma$ if and only if

$$
\sigma \log \frac{\alpha}{\omega}>\frac{\partial \log \mu}{\partial \log (s / m)} \in(0,1)
$$

which is satisfied if, but not only if, $\log (\alpha / \omega)>1$. 


\section{References}

[1] Acs, Z., Armington, C., 2006. Entrepreneurship, Geography and American Economic Growth, Cambridge University Press, New York, NY.

[2] Black, J., de Meza, D., Jeffreys, D., 1996. House prices, the supply of collateral, and the enterprise economy, Economic Journal 106, 60-75.

[3] Buenstorf, G., Klepper, S., 2007. Why does entry cluster geographically? Evidence from the US tire industry, Working Paper.

[4] Carlino, G., Hunt, R., 2007. Innovation across U.S. industries: The effects of local economic characteristics, Working Paper.

[5] Carlino, G., Saiz, A., 2007. Beautiful city, Working Paper.

[6] Chen, Y., Rosenthal, S., 2008. Local amenities and life-cycle migration: Do people move for jobs or fun?, Journal of Urban Economics 64, 519-537.

[7] Chinitz, B., 1961. Contrasts in agglomeration: New York and Pittsburgh, American Economic Review 51:2, 279-289.

[8] Davis, S., Haltiwanger, J., Schuh, S., 1996. Job Creation and Destruction, MIT Press, Cambridge, MA.

[9] Delgado, M., Porter, M., Stern, S., 2008. Convergence, clusters and economic performance, Working Paper.

[10] Delgado, M., Porter, M., Stern, S., 2009. Clusters and entrepreneurship, Working Paper.

[11] Dixit, A., Stiglitz, J., 1977. Monopolistic competition and optimum product diversity, American Economic Review 67, 297-308.

[12] Doms, M., Lewis, E., Robb, A., 2010. Local labor force education, new business characteristics, and firm performance, Journal of Urban Economics, this issue.

[13] Drucker, J., Feser, E., 2007. Regional industrial dominance, agglomeration economies, and manufacturing plant productivity, CES Working Paper 07-31.

[14] Dunne, T., Roberts, M., Samuelson, L., 1989a. Patterns of firm entry and exit in U.S. manufacturing industries, RAND Journal of Economics 19, 495-515.

[15] Dunne, T., Roberts, M., Samuelson, L., 1989b. Plant turnover and gross employment flows in the U.S. manufacturing sector, Journal of Labor Economics 7, 48-71.

[16] Duranton, G., 2007. Urban evolutions: The fast, the slow, and the still, American Economic Review 97:1, 197-221.

[17] Duranton, G., Puga, D., 2001. Nursery cities: Urban diversity, process innovation, and the life cycle of products, American Economic Review 91:5, 1454-1477.

[18] Ellison, G., Glaeser, E., 1999. The geographic concentration of industry: Does natural advantage explain agglomeration?, Papers and Proceedings, American Economic Review 89, 311-316.

[19] Ellison, G., Glaeser, E., Kerr, W., 2009. What causes industry agglomeration? Evidence from coagglomeration patterns, American Economic Review, forthcoming. 
[20] Evans, D., Jovanovic, B., 1989. An estimated model of entrepreneurial choice under liquidity constraints, Journal of Political Economy 97:4, 808-827.

[21] Faberman, J., 2007. The relationship between the establishment age distribution and urban growth, Working Paper.

[22] Figueiredo, O., Guimaraes, P., Woodward, D., 2002. Home-field advantage: Location decisions of Portuguese entrepreneurs, Journal of Urban Economics 52:2, 341-361.

[23] Gabriel, S., Rosenthal, S., 2004. Quality of the business environment versus quality of life: Do firms and households like the same cities? Review of Economics and Statistics 86, 438-444.

[24] Glaeser, E., 2007. Entrepreneurship and the city, NBER Working Paper 13551.

[25] Glaeser, E., Kallal, H., Scheinkman, J., Shleifer, A., 1992. Growth in cities, Journal of Political Economy 100, 1126-1152.

[26] Glaeser, E., Kerr, W., 2009. Local industrial conditions and entrepreneurship: How much of the spatial distribution can we explain?, Journal of Economics and Management Strategy $18: 3,623-663$.

[27] Glaeser, E., Kolko, J., Saiz, A., 2001. Consumer city, Journal of Economic Geography 1, $27-50$.

[28] Grossman, G., Helpman, E., 2002. Integration versus outsourcing in industry equilibrium, Quarterly Journal of Economics 117:1, 85-120.

[29] Haltiwanger, J., Jarmin, R., Krizan, C.J., 2010. Mom-and-pop meet big-box: Complements or substitutes?, Journal of Urban Economics, this issue.

[30] Holmes, T., Lee, S., 2009. Economies of density versus natural advantage: Crop choice on the back forty, Working Paper.

[31] Hurst, E., Lusardi, A., 2004. Liquidity constraints, household wealth, and entrepreneurship, Journal of Political Economy 112:2, 319-347.

[32] Jacobs, J., 1970. The Economy of Cities, Vintage Books, New York, NY.

[33] Jarmin, R., Miranda, J., 2002. The longitudinal business database, CES Working Paper.

[34] Jovanovic, B., MacDonald, G., 1994. The life cycle of a competitive industry, The Journal of Political Economy 102:2, 322-347.

[35] Kerr, W., 2010. Breakthrough inventions and migrating clusters of innovation, Journal of Urban Economics, this issue.

[36] Kerr, W., Nanda, R., 2009a. Democratizing entry: Banking deregulations, financing constraints, and entrepreneurship, Journal of Financial Economics 94:1, 124-149.

[37] Kerr, W., Nanda, R., 2009b. Banking deregulations, financing constraints, and firm entry size, HBS Working Paper 10-010.

[38] Klepper, S., Graddy, E., 1990. The evolution of new industries and the determinants of market structure, The RAND Journal of Economics 21:1, 27-44.

[39] Li, B., Yu, Y., 2009. Geographic concentration and vertical disintegration: Evidence from China, Journal of Urban Economics 65:3, 294-304. 
[40] Marx, M., Strumsky, D., Fleming, L., 2007. Noncompetes and inventor mobility: Specialists, stars, and the Michigan experiment, HBS Working Paper 07-042.

[41] Michelacci, C., Silva, O., 2007. Why so many local entrepreneurs?, Review of Economics and Statistics 89:4, 615-633.

[42] Miracky, W., 1993. Economic Growth and Business Cycles in Cities: The Role of Locational Externalities, MIT Thesis.

[43] Nanda, R., 2009. Entrepreneurship and the discipline of external finance, HBS Working Paper 08-047.

[44] Rosenthal, S., Ross, A., 2010. Violent crime, entrepreneurship, and cities, Journal of Urban Economics, this issue.

[45] Rosenthal, S., Strange, W., 2001. The determinants of agglomeration, Journal of Urban Economics 50, 191-229.

[46] Rosenthal, S., Strange, W., 2009. Small establishments/big effects: Agglomeration, industrial organization and entrepreneurship, forthcoming in Glaeser, E. (Ed.), Economics of Agglomeration, University of Chicago Press, Chicago, IL.

[47] Saxenian, A., 1994. Regional Advantage: Culture and Competition in Silicon Valley and Route 128, Harvard University Press, Cambridge, MA. 


\section{Figure 1: Employment Growth and Firms per Worker}

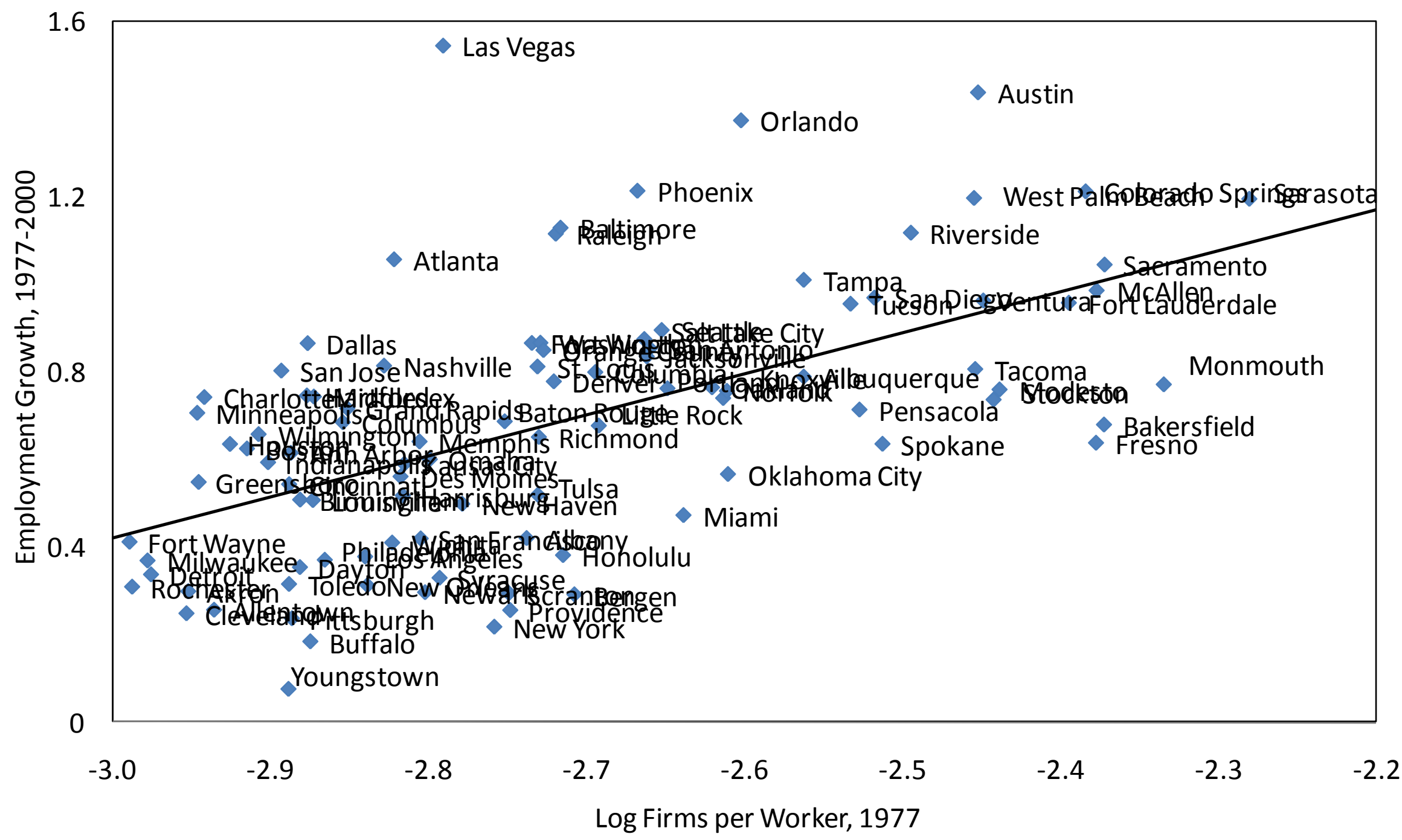

Notes: Figure graphs employment growth by city over 1977-2000 against the number of firms per worker in 1977. 
Figure 2a: Start-Up Elasticity to Average Establishment Size by Sector

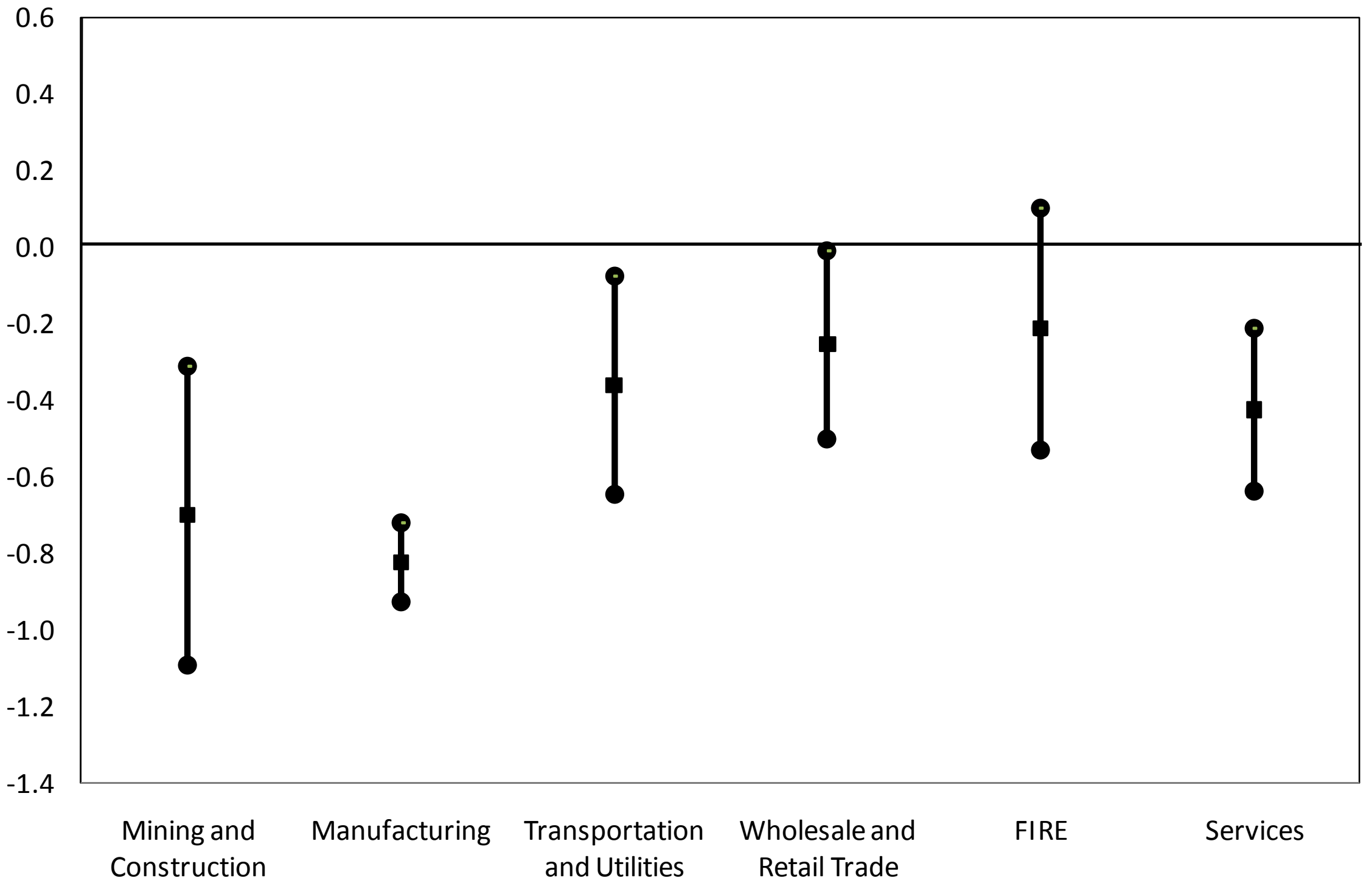

Notes: Figure reports elasticity estimates of log entry employment by sector over 1992-1999 to log average establishment size in 1992. A negative elasticity means greater entry is associated with smaller establishments in the incumbent industrial structure. Regressions employ region-industry variation, include region and industry fixed effects, and control for log initial employment in region-industry. Squares represent point estimates, and end points provide two standard error confidence bands. The appendix documents the complete estimations. 


\section{Figure 2b: Facility Expansion Elasticity to Average Est. Size by Sector}

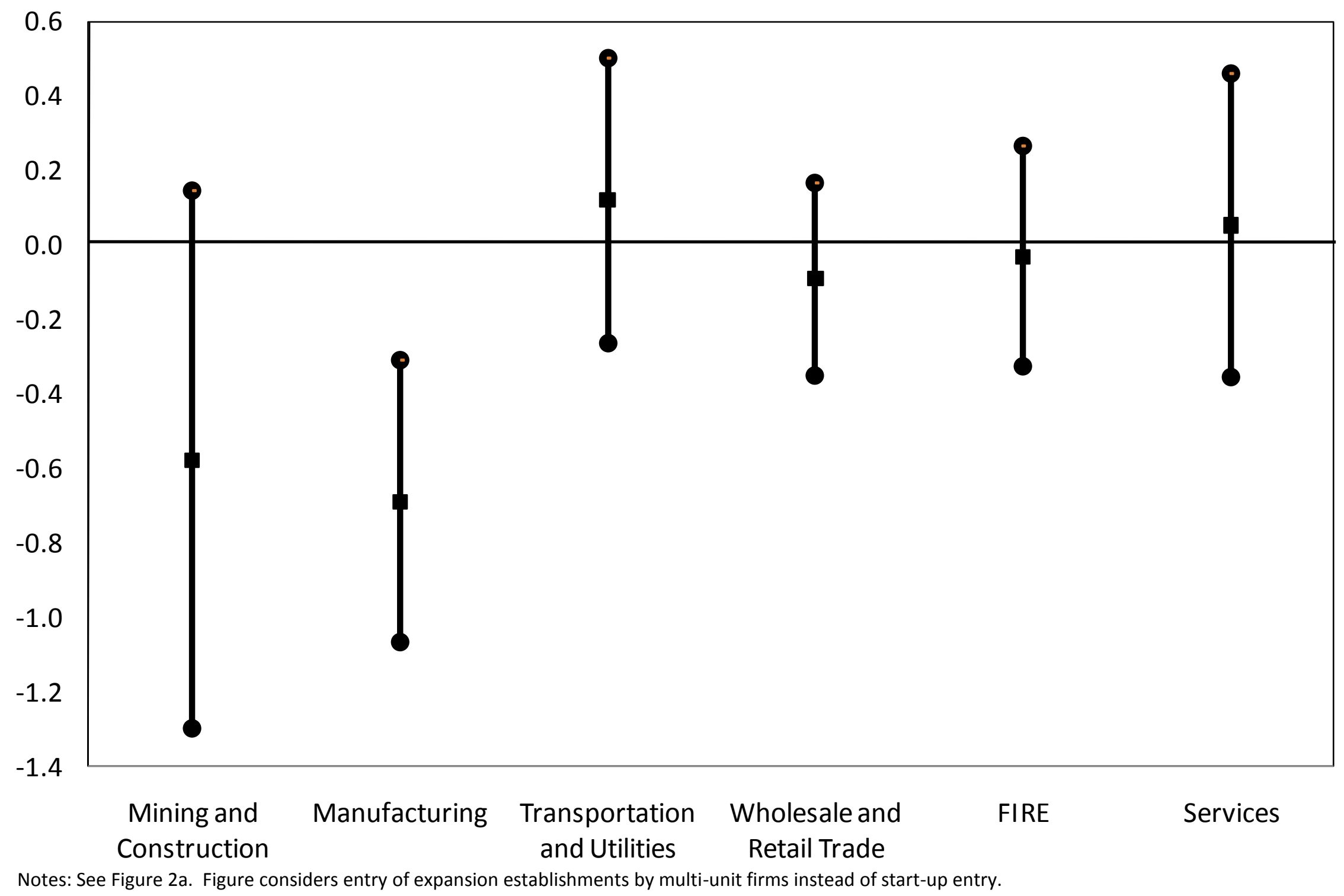


Table 1: LBD Descriptive Statistics on US Entry Rates

\begin{tabular}{|c|c|c|c|}
\hline & $\begin{array}{c}\text { All } \\
\text { Entering } \\
\text { Establishments }\end{array}$ & $\begin{array}{l}\text { Establishments } \\
\text { of New } \\
\text { Startup Firms }\end{array}$ & $\begin{array}{c}\text { Facility } \\
\text { Expansions } \\
\text { of Existing Firms }\end{array}$ \\
\hline Mean Annual Entry Counts & 704,784 & 564,024 & 140,761 \\
\hline Mean Annual Entry Employment & $7,259,444$ & $3,819,081$ & $3,440,362$ \\
\hline Mean Annual Entry Size & 10.3 & 6.8 & 24.4 \\
\hline \multicolumn{4}{|l|}{ Entry Counts by Entry Size } \\
\hline 1-5 Employees & $70 \%$ & $77 \%$ & $44 \%$ \\
\hline 6-20 Employees & $22 \%$ & $19 \%$ & $35 \%$ \\
\hline 21-100 Employees & $7 \%$ & $4 \%$ & $17 \%$ \\
\hline 101+ Employees & $1 \%$ & $1 \%$ & $4 \%$ \\
\hline \multicolumn{4}{|l|}{ Entry Counts by Sector } \\
\hline Mining & $0 \%$ & $0 \%$ & $0 \%$ \\
\hline Construction & $10 \%$ & $13 \%$ & $1 \%$ \\
\hline Manufacturing & $5 \%$ & $5 \%$ & $3 \%$ \\
\hline Transportation \& Utilities & $5 \%$ & $5 \%$ & $7 \%$ \\
\hline Wholesale Trade & $8 \%$ & $8 \%$ & $9 \%$ \\
\hline Retail Trade & $24 \%$ & $23 \%$ & $32 \%$ \\
\hline Finance, Ins., \& Real Estate & $10 \%$ & $8 \%$ & $18 \%$ \\
\hline Services & $37 \%$ & $39 \%$ & $30 \%$ \\
\hline \multicolumn{4}{|l|}{ Entry Counts by Region } \\
\hline Northeast & $18 \%$ & $19 \%$ & $17 \%$ \\
\hline South & $36 \%$ & $36 \%$ & $38 \%$ \\
\hline Midwest & $22 \%$ & $21 \%$ & $23 \%$ \\
\hline West Coast & $24 \%$ & $24 \%$ & $23 \%$ \\
\hline
\end{tabular}

Notes: Descriptive statistics for entering establishments in the Longitudinal Business Database from 1992-1998. Jarmin and Miranda (2002) describe the construction of the LBD. Sectors not included are agriculture, forestry and fishing, public administration, the US postal service, and private households. 
Table 2: Entry Rates and Regional Industrial Structure

\begin{tabular}{|c|c|c|c|c|c|c|}
\hline & $\begin{array}{l}\text { Startup } \\
\text { Entry }\end{array}$ & $\begin{array}{l}\text { Startup } \\
\text { Entry }\end{array}$ & $\begin{array}{l}\text { Startup } \\
\text { Entry }\end{array}$ & $\begin{array}{l}\text { Facility } \\
\text { Expansions }\end{array}$ & $\begin{array}{l}\text { Facility } \\
\text { Expansions }\end{array}$ & $\begin{array}{l}\text { Facility } \\
\text { Expansions }\end{array}$ \\
\hline & $(1)$ & $(2)$ & (3) & (4) & $(5)$ & (6) \\
\hline & \multicolumn{6}{|c|}{$\begin{array}{l}\text { Dep. Variable is Log Average Employment in Entering } \\
\text { Establishments over 1992-1999 by Region-Industry }\end{array}$} \\
\hline & \multicolumn{6}{|c|}{ A. Entry and Average Establishment Size } \\
\hline $\begin{array}{l}\text { Log } 1992 \text { Total Employment } \\
\text { in Region-Industry }\end{array}$ & $\begin{array}{c}0.972 \\
(0.010)\end{array}$ & $\begin{array}{c}0.810 \\
(0.036)\end{array}$ & $\begin{array}{c}0.968 \\
(0.009)\end{array}$ & $\begin{array}{c}1.105 \\
(0.016)\end{array}$ & $\begin{array}{c}0.943 \\
(0.057)\end{array}$ & $\begin{array}{c}1.096 \\
(0.016)\end{array}$ \\
\hline $\begin{array}{l}\text { Log } 1992 \text { Av. Establishment } \\
\text { Size in Region-Industry }\end{array}$ & $\begin{array}{l}-0.674 \\
(0.013)\end{array}$ & $\begin{array}{l}-0.638 \\
(0.046)\end{array}$ & $\begin{array}{l}-0.633 \\
(0.020)\end{array}$ & $\begin{array}{l}-0.432 \\
(0.030)\end{array}$ & $\begin{array}{l}-0.340 \\
(0.125)\end{array}$ & $\begin{array}{l}-0.317 \\
(0.026)\end{array}$ \\
\hline Adjusted R-Squared & 0.83 & 0.93 & & 0.72 & 0.89 & \\
\hline Region Fixed Effects & $\mathrm{X}$ & $X$ & $\mathrm{X}$ & $\mathrm{X}$ & $\mathrm{X}$ & $X$ \\
\hline Industry Fixed Effects & & $X$ & & & $\mathrm{X}$ & \\
\hline \multirow[t]{2}{*}{ Estimation Technique } & OLS & OLS & IV & OLS & OLS & IV \\
\hline & \multicolumn{6}{|c|}{ B. Entry and HHI Concentration Index } \\
\hline $\begin{array}{l}\text { Log } 1992 \text { Total Employment } \\
\text { in Region-Industry }\end{array}$ & $\begin{array}{c}0.634 \\
(0.020)\end{array}$ & $\begin{array}{c}0.475 \\
(0.030)\end{array}$ & $\begin{array}{c}0.511 \\
(0.023)\end{array}$ & $\begin{array}{c}0.905 \\
(0.031)\end{array}$ & $\begin{array}{c}0.754 \\
(0.060)\end{array}$ & $\begin{array}{c}0.826 \\
(0.027)\end{array}$ \\
\hline $\begin{array}{l}\text { Log } 1992 \text { HHI Concentration } \\
\text { in Region-Industry }\end{array}$ & $\begin{array}{l}-0.418 \\
(0.021)\end{array}$ & $\begin{array}{l}-0.167 \\
(0.021)\end{array}$ & $\begin{array}{l}-0.597 \\
(0.028)\end{array}$ & $\begin{array}{l}-0.243 \\
(0.028)\end{array}$ & $\begin{array}{l}-0.120 \\
(0.030)\end{array}$ & $\begin{array}{l}-0.359 \\
(0.025)\end{array}$ \\
\hline Adjusted R-Squared & 0.77 & 0.93 & & 0.70 & 0.89 & \\
\hline Region Fixed Effects & $X$ & $X$ & $\mathrm{X}$ & $\mathrm{X}$ & $\mathrm{X}$ & $X$ \\
\hline Industry Fixed Effects & & $\mathrm{X}$ & & & $\mathrm{X}$ & \\
\hline Estimation Technique & OLS & OLS & IV & OLS & OLS & IV \\
\hline \multicolumn{7}{|c|}{$\begin{array}{l}\text { Notes: Estimations quantify the relationship between entry and industrial structure. The dependent variables are log entry } \\
\text { employments of new firms or facility expansions by region-industry taken from the LBD. Entry employments are annual } \\
\text { averages for region-industries over the } 1992-1999 \text { period. Regions are classified by the nine Census regions, and industries } \\
\text { are classified at the SIC3 level ( } 349 \text { in total). The explanatory variables of total employments, average establishment size, } \\
\text { and concentration are calculated from initial values in } 1992 \text { by region-industry. The region with the least industry } \\
\text { employment is excluded for each industry in both OLS and IV specifications. IV regressions instrument for observed region- } \\
\text { industry average establishment size or concentration with the } 1992 \text { level in the excluded region by industry. The first stage } \\
\text { relationships are } 0.925 \text { ( } 0.020) \text { and } 0.731(0.011) \text {, respectively. Estimations report clustered standard errors, are unweighted, } \\
\text { and have } 2,712 \text { observations. The decline in observations from the theoretical level of } 2,792 \text { is due to cases where an } \\
\text { industry is not present in every region. Weighted regressions employing } 1992 \text { industry sizes as weights produce similar } \\
\text { results. The appendix reports these regressions by sector. }\end{array}$} \\
\hline
\end{tabular}


Table 3: Entry Size Distribution and Regional Industrial Structure

\begin{tabular}{|c|c|c|c|c|c|}
\hline \multirow[b]{5}{*}{$\begin{array}{l}\text { Log } 1992 \text { Total Employment } \\
\text { in Region-Industry }\end{array}$} & \multirow{3}{*}{$\begin{array}{c}\text { Total } \\
\text { Entry }\end{array}$} & \multicolumn{4}{|c|}{ Entering Employment Of } \\
\hline & & $1-5$ & $6-20$ & $21-100$ & $101+$ \\
\hline & & $(2)$ & (3) & (4) & $(5)$ \\
\hline & \multicolumn{5}{|c|}{$\begin{array}{c}\text { Dep. Variable is Log Average Employment in Entering } \\
\text { Establishments over 1992-1999 by Region-Industry }\end{array}$} \\
\hline & $\begin{array}{c}0.972 \\
(0.010)\end{array}$ & $\begin{array}{c}0.915 \\
(0.010)\end{array}$ & $\begin{array}{c}0.910 \\
(0.006)\end{array}$ & $\begin{array}{c}0.916 \\
(0.008)\end{array}$ & $\begin{array}{c}1.011 \\
(0.028)\end{array}$ \\
\hline $\begin{array}{l}\text { Log } 1992 \text { Av. Establishment } \\
\text { Size in Region-Industry }\end{array}$ & $\begin{array}{l}-0.674 \\
(0.013)\end{array}$ & $\begin{array}{l}-1.223 \\
(0.012)\end{array}$ & $\begin{array}{l}-0.963 \\
(0.012)\end{array}$ & $\begin{array}{l}-0.476 \\
(0.013)\end{array}$ & $\begin{array}{l}-0.014 \\
(0.026)\end{array}$ \\
\hline Adjusted R-Squared & 0.83 & 0.87 & 0.85 & 0.75 & 0.51 \\
\hline Region Fixed Effects & $\mathrm{X}$ & $\mathrm{X}$ & $\mathrm{X}$ & $\mathrm{X}$ & $\mathrm{X}$ \\
\hline & \multicolumn{5}{|c|}{ B. Entry and HHI Concentration Index } \\
\hline $\begin{array}{l}\text { Log } 1992 \text { Total Employment } \\
\text { in Region-Industry }\end{array}$ & $\begin{array}{c}0.634 \\
(0.020)\end{array}$ & $\begin{array}{c}0.326 \\
(0.033)\end{array}$ & $\begin{array}{c}0.416 \\
(0.025)\end{array}$ & $\begin{array}{c}0.682 \\
(0.012)\end{array}$ & $\begin{array}{l}1.088 \\
(0.037)\end{array}$ \\
\hline $\begin{array}{l}\text { Log } 1992 \text { HHI Concentration } \\
\text { in Region-Industry }\end{array}$ & $\begin{array}{l}-0.418 \\
(0.021)\end{array}$ & $\begin{array}{l}-0.724 \\
(0.023)\end{array}$ & $\begin{array}{l}-0.614 \\
(0.024)\end{array}$ & $\begin{array}{l}-0.288 \\
(0.017)\end{array}$ & $\begin{array}{c}0.113 \\
(0.019)\end{array}$ \\
\hline Adjusted R-Squared & 0.77 & 0.68 & 0.74 & 0.71 & 0.51 \\
\hline Region Fixed Effects & $\mathrm{X}$ & $X$ & $\mathrm{X}$ & $X$ & $X$ \\
\hline
\end{tabular}

Notes: See Table 2. Estimations quantify the relationship between entry and industrial structure across the entry size distribution. Entering employments are for the first year of establishment observation. 
Table 4: Labor Returns and Regional Industrial Structure

\begin{tabular}{|c|c|c|c|c|}
\hline & \multicolumn{2}{|c|}{$\begin{array}{c}\text { Log } 1997 \text { Labor Returns } \\
\text { in Single-Unit Firms in } \\
\text { Region-Industry }\end{array}$} & \multicolumn{2}{|c|}{$\begin{array}{c}\text { Log } 1997 \text { Labor Returns } \\
\text { in Multi-Unit Firms in } \\
\text { Region-Industry }\end{array}$} \\
\hline & $(1)$ & $(2)$ & $(3)$ & $(4)$ \\
\hline & \multicolumn{4}{|c|}{$\begin{array}{l}\text { Dep. Variable is Log } 1997 \text { Dollar Value of Shipments } \\
\text { Over Employee Count by Region-Industry }\end{array}$} \\
\hline & \multicolumn{4}{|c|}{ Labor Returns and Regional Industry Structure } \\
\hline $\begin{array}{l}\text { Log } 1992 \text { Total Employment } \\
\text { in Region-Industry }\end{array}$ & $\begin{array}{c}0.055 \\
(0.025)\end{array}$ & $\begin{array}{c}0.041 \\
(0.009)\end{array}$ & $\begin{array}{c}0.044 \\
(0.015)\end{array}$ & $\begin{array}{c}0.065 \\
(0.017)\end{array}$ \\
\hline $\begin{array}{l}\text { Log } 1992 \text { Av. Establishment } \\
\text { Size in Region-Industry }\end{array}$ & $\begin{array}{l}-0.030 \\
(0.044)\end{array}$ & & $\begin{array}{c}0.042 \\
(0.026)\end{array}$ & \\
\hline $\begin{array}{l}\text { Log } 1992 \text { HHI Concentration } \\
\text { in Region-Industry }\end{array}$ & & $\begin{array}{l}-0.004 \\
(0.013)\end{array}$ & & $\begin{array}{c}0.010 \\
(0.014)\end{array}$ \\
\hline Adjusted R-Squared & 0.83 & 0.83 & 0.89 & 0.89 \\
\hline Region Fixed Effects & $\mathrm{X}$ & $\mathrm{X}$ & $\mathrm{X}$ & $X$ \\
\hline Industry Fixed Effects & $\mathrm{X}$ & $X$ & $X$ & $X$ \\
\hline
\end{tabular}


Table 5: Entry Rates and Regional Industry Age Distribution

\begin{tabular}{|c|c|c|c|c|c|c|}
\hline & $\begin{array}{l}\text { Startup } \\
\text { Entry }\end{array}$ & $\begin{array}{l}\text { Startup } \\
\text { Entry }\end{array}$ & $\begin{array}{l}\text { Startup } \\
\text { Entry }\end{array}$ & $\begin{array}{l}\text { Facility } \\
\text { Expansions }\end{array}$ & $\begin{array}{l}\text { Facility } \\
\text { Expansions }\end{array}$ & $\begin{array}{l}\text { Facility } \\
\text { Expansions }\end{array}$ \\
\hline & $(1)$ & $(2)$ & (3) & (4) & $(5)$ & $(6)$ \\
\hline & \multicolumn{6}{|c|}{$\begin{array}{c}\text { Dep. Variable is Log Average Employment in Entering } \\
\text { Establishments over 1992-1999 by Region-Industry }\end{array}$} \\
\hline $\begin{array}{l}\text { Log } 1992 \text { Total Employment } \\
\text { in Region-Industry }\end{array}$ & $\begin{array}{c}0.578 \\
(0.031)\end{array}$ & $\begin{array}{c}0.804 \\
(0.039)\end{array}$ & $\begin{array}{c}0.522 \\
(0.029)\end{array}$ & $\begin{array}{c}0.847 \\
(0.053)\end{array}$ & $\begin{array}{c}0.981 \\
(0.047)\end{array}$ & $\begin{array}{l}0.806 \\
(0.057)\end{array}$ \\
\hline $\begin{array}{l}\text { Log } 1992 \text { Mean Establish. } \\
\text { Age in Region-Industry }\end{array}$ & $\begin{array}{l}-0.527 \\
(0.142)\end{array}$ & $\begin{array}{l}-0.439 \\
(0.119)\end{array}$ & $\begin{array}{l}-0.558 \\
(0.136)\end{array}$ & $\begin{array}{l}-0.598 \\
(0.161)\end{array}$ & $\begin{array}{l}-0.553 \\
(0.180)\end{array}$ & $\begin{array}{l}-0.621 \\
(0.163)\end{array}$ \\
\hline $\begin{array}{l}\text { Log } 1992 \text { Av. Establishment } \\
\text { Size in Region-Industry }\end{array}$ & & $\begin{array}{l}-0.619 \\
(0.040)\end{array}$ & & & $\begin{array}{l}-0.317 \\
(0.124)\end{array}$ & \\
\hline $\begin{array}{l}\text { Log } 1992 \text { HHI Concentration } \\
\text { in Region-Industry }\end{array}$ & & & $\begin{array}{l}-0.173 \\
(0.023)\end{array}$ & & & $\begin{array}{l}-0.126 \\
(0.029)\end{array}$ \\
\hline Adjusted R-Squared & 0.92 & 0.93 & 0.92 & 0.89 & 0.89 & 0.89 \\
\hline Region Fixed Effects & $\mathrm{X}$ & $\mathrm{X}$ & $\mathrm{X}$ & $\mathrm{X}$ & $\mathrm{X}$ & $\mathrm{X}$ \\
\hline Industry Fixed Effects & $\mathrm{X}$ & $\mathrm{X}$ & $\mathrm{X}$ & $X$ & $X$ & $X$ \\
\hline
\end{tabular}

Notes: See Table 2. Estimations quantify the relationship between entry and mean age of establishments by region-industry. 
Table 6A: Entry Rates and City-Level Industrial Structure

\begin{tabular}{|c|c|c|c|c|}
\hline & $\begin{array}{l}\text { Startup } \\
\text { Entry }\end{array}$ & $\begin{array}{l}\text { Startup } \\
\text { Entry }\end{array}$ & $\begin{array}{l}\text { Facility } \\
\text { Expansions }\end{array}$ & $\begin{array}{l}\text { Facility } \\
\text { Expansions }\end{array}$ \\
\hline & (1) & (2) & (3) & (4) \\
\hline & \multicolumn{4}{|c|}{$\begin{array}{c}\text { Dep. Variable is Log Average Employment in Entering } \\
\text { Establishments over 1992-1999 by City-Industry }\end{array}$} \\
\hline $\begin{array}{l}\text { Log } 1992 \text { Total Employment } \\
\text { in City }\end{array}$ & $\begin{array}{c}0.237 \\
(0.012)\end{array}$ & & $\begin{array}{c}0.335 \\
(0.016)\end{array}$ & \\
\hline $\begin{array}{l}\text { Log } 1992 \text { Total Employment } \\
\text { in City-Industry }\end{array}$ & $\begin{array}{c}0.860 \\
(0.012)\end{array}$ & $\begin{array}{c}0.794 \\
(0.013)\end{array}$ & $\begin{array}{c}0.779 \\
(0.016)\end{array}$ & $\begin{array}{c}0.755 \\
(0.018)\end{array}$ \\
\hline $\begin{array}{l}\text { Log } 1992 \text { Av. Establishment } \\
\text { Size in City }\end{array}$ & $\begin{array}{l}-0.283 \\
(0.040)\end{array}$ & & $\begin{array}{c}0.106 \\
(0.053)\end{array}$ & \\
\hline $\begin{array}{l}\text { Log } 1992 \text { Av. Establishment } \\
\text { Size in City-Industry }\end{array}$ & $\begin{array}{l}-0.802 \\
(0.019)\end{array}$ & $\begin{array}{l}-0.673 \\
(0.021)\end{array}$ & $\begin{array}{l}-0.553 \\
(0.024)\end{array}$ & $\begin{array}{l}-0.470 \\
(0.027)\end{array}$ \\
\hline Adjusted R-Squared & 0.87 & 0.88 & 0.80 & 0.81 \\
\hline $\begin{array}{l}\text { City Fixed Effects } \\
\text { Industry Fixed Effects }\end{array}$ & $X$ & $\begin{array}{l}X \\
X\end{array}$ & $X$ & $\begin{array}{l}X \\
X\end{array}$ \\
\hline \multicolumn{5}{|c|}{$\begin{array}{l}\text { Notes: Estimations quantify the relationship between entry and city-level industrial structure. The } \\
\text { dependent variables are log entry employments of new firms or facility expansions by city-industry taken } \\
\text { from the LBD. Entry employments are annual averages for city-industries over the } 1992-1999 \text { period. } \\
\text { Cities are classified by } 273 \text { PMSAs excluding AK and HI, and industries are classified at the SIC2 level (66 } \\
\text { in total). The explanatory variables of total employments, average establishment size, and concentration are } \\
\text { calculated from initial values in } 1992 \text { by city-industry. Estimations report robust standard errors, are } \\
\text { unweighted, and have 16,363 observations. The decline in observations from the theoretical level of 18,018 } \\
\text { is due to cases where an industry is not present in every city. Weighted regressions employing an interaction } \\
\text { of average industry size across cities with average size of industries within a city as weights produce similar } \\
\text { results. }\end{array}$} \\
\hline
\end{tabular}


Table 6B: Entry Rates and City-Level Industrial Structure

\begin{tabular}{|c|c|c|c|c|}
\hline & $\begin{array}{l}\text { Startup } \\
\text { Entry }\end{array}$ & $\begin{array}{l}\text { Startup } \\
\text { Entry }\end{array}$ & $\begin{array}{l}\text { Facility } \\
\text { Expansions }\end{array}$ & $\begin{array}{l}\text { Facility } \\
\text { Expansions }\end{array}$ \\
\hline & $(1)$ & $(2)$ & (3) & $(4)$ \\
\hline & \multicolumn{4}{|c|}{$\begin{array}{c}\text { Dep. Variable is Log Average Employment in Entering } \\
\text { Establishments over 1992-1999 by City-Industry }\end{array}$} \\
\hline & \multicolumn{4}{|c|}{ Entry and HHI Concentration Index } \\
\hline $\begin{array}{l}\text { Log } 1992 \text { Total Employment } \\
\text { in City }\end{array}$ & $\begin{array}{c}0.402 \\
(0.011)\end{array}$ & & $\begin{array}{c}0.472 \\
(0.014)\end{array}$ & \\
\hline $\begin{array}{l}\text { Log } 1992 \text { Total Employment } \\
\text { in City-Industry }\end{array}$ & $\begin{array}{c}0.364 \\
(0.009)\end{array}$ & $\begin{array}{c}0.383 \\
(0.008)\end{array}$ & $\begin{array}{c}0.438 \\
(0.012)\end{array}$ & $\begin{array}{c}0.471 \\
(0.011)\end{array}$ \\
\hline $\begin{array}{l}\text { Log } 1992 \text { HHI Concentration } \\
\text { in City }\end{array}$ & $\begin{array}{l}-0.092 \\
(0.009)\end{array}$ & & $\begin{array}{l}-0.071 \\
(0.011)\end{array}$ & \\
\hline $\begin{array}{l}\text { Log } 1992 \text { HHI Concentration } \\
\text { in City-Industry }\end{array}$ & $\begin{array}{l}-0.273 \\
(0.011)\end{array}$ & $\begin{array}{c}-0.223 \\
(0.011)\end{array}$ & $\begin{array}{l}-0.159 \\
(0.014)\end{array}$ & $\begin{array}{c}-0.134 \\
(0.014)\end{array}$ \\
\hline Adjusted R-Squared & 0.86 & 0.87 & 0.80 & 0.81 \\
\hline City Fixed Effects & & $\mathrm{X}$ & & $X$ \\
\hline Industry Fixed Effects & $\mathrm{X}$ & $X$ & $\mathrm{X}$ & $X$ \\
\hline
\end{tabular}

Notes: See Table 6A. 
Table 7: Entry Rates and Industry Labor Intensity

\begin{tabular}{|c|c|c|c|c|}
\hline & $\begin{array}{l}\text { Startup } \\
\text { Entry }\end{array}$ & $\begin{array}{l}\text { Startup } \\
\text { Entry }\end{array}$ & $\begin{array}{l}\text { Facility } \\
\text { Expansions }\end{array}$ & $\begin{array}{l}\text { Facility } \\
\text { Expansions }\end{array}$ \\
\hline & (1) & $(2)$ & (3) & (4) \\
\hline & \multicolumn{4}{|c|}{$\begin{array}{c}\text { Dep. Variable is Log Average Employment in Entering } \\
\text { Establishments over 1992-1999 by Region-Industry }\end{array}$} \\
\hline & \multicolumn{4}{|c|}{ A. Labor Intensity Only } \\
\hline $\begin{array}{l}\text { Log } 1992 \text { Total Employment } \\
\text { in Region-Industry }\end{array}$ & $\begin{array}{c}0.913 \\
(0.011)\end{array}$ & $\begin{array}{c}0.910 \\
(0.011)\end{array}$ & $\begin{array}{c}1.075 \\
(0.016)\end{array}$ & $\begin{array}{l}1.074 \\
(0.016)\end{array}$ \\
\hline $\begin{array}{l}\text { Log } 1992 \text { Labor Intensity } \\
\text { in Region-Industry }\end{array}$ & $\begin{array}{c}0.377 \\
(0.040)\end{array}$ & $\begin{array}{c}0.536 \\
(0.034)\end{array}$ & $\begin{array}{l}-0.202 \\
(0.041)\end{array}$ & $\begin{array}{l}-0.178 \\
(0.027)\end{array}$ \\
\hline Adjusted R-Squared & 0.70 & & 0.68 & \\
\hline Region Fixed Effects & $X$ & $\mathrm{X}$ & $X$ & $X$ \\
\hline \multirow[t]{2}{*}{ Estimation Technique } & OLS & IV & OLS & IV \\
\hline & \multicolumn{4}{|c|}{ B. Labor Intensity and Regional Industrial Structure } \\
\hline $\begin{array}{l}\text { Log } 1992 \text { Total Employment } \\
\text { in Region-Industry }\end{array}$ & $\begin{array}{c}0.966 \\
(0.010)\end{array}$ & $\begin{array}{c}0.961 \\
(0.009)\end{array}$ & $\begin{array}{c}1.111 \\
(0.015)\end{array}$ & $\begin{array}{c}1.103 \\
(0.016)\end{array}$ \\
\hline $\begin{array}{l}\text { Log } 1992 \text { Labor Intensity } \\
\text { in Region-Industry }\end{array}$ & $\begin{array}{c}0.274 \\
(0.030)\end{array}$ & $\begin{array}{c}0.317 \\
(0.037)\end{array}$ & $\begin{array}{l}-0.272 \\
(0.036)\end{array}$ & $\begin{array}{l}-0.300 \\
(0.034)\end{array}$ \\
\hline $\begin{array}{l}\text { Log } 1992 \text { Av. Establishment } \\
\text { Size in Region-Industry }\end{array}$ & $\begin{array}{l}-0.659 \\
(0.011)\end{array}$ & $\begin{array}{l}-0.612 \\
(0.018)\end{array}$ & $\begin{array}{l}-0.446 \\
(0.031)\end{array}$ & $\begin{array}{l}-0.336 \\
(0.027)\end{array}$ \\
\hline Adjusted R-Squared & 0.83 & & 0.73 & \\
\hline Region Fixed Effects & $\mathrm{X}$ & $\mathrm{X}$ & $\mathrm{X}$ & $\mathrm{X}$ \\
\hline Estimation Technique & OLS & IV & OLS & IV \\
\hline
\end{tabular}

Notes: See Table 2. Estimations quantify the relationship between entry and industry labor intensity. Labor intensity is measured as payroll divided by total sales. The region with the least industry employment is excluded for each industry in both OLS and IV specifications. IV regressions instrument for observed region-industry labor intensity with the 1992 intensity in the excluded region by industry. The first stage relationship is 0.815 (0.014). 
Table 8: Amenities, Industry Location, and Entrepreneurship

\begin{tabular}{|c|c|c|c|c|c|c|c|c|}
\hline & $\begin{array}{c}\text { Total } \\
\text { Employment }\end{array}$ & $\begin{array}{l}\text { Total } \\
\text { Employment }\end{array}$ & $\begin{array}{l}\text { Startup } \\
\text { Entry }\end{array}$ & $\begin{array}{l}\text { Startup } \\
\text { Entry }\end{array}$ & $\begin{array}{l}\text { Startup } \\
\text { Entry }\end{array}$ & $\begin{array}{c}\text { Facility } \\
\text { Expansions }\end{array}$ & $\begin{array}{c}\text { Facility } \\
\text { Expansions }\end{array}$ & $\begin{array}{c}\text { Facility } \\
\text { Expansions }\end{array}$ \\
\hline & $(1)$ & $(2)$ & $(3)$ & $(4)$ & $(5)$ & $(6)$ & $(7)$ & $(8)$ \\
\hline & \multicolumn{8}{|c|}{ Dependent Variable is Log Employment in Indicated Type of Establishment over 1992-1999 by City-Industry } \\
\hline City-Level Amenities & $\begin{array}{c}0.964 \\
(0.076)\end{array}$ & & $\begin{array}{c}0.489 \\
(0.035)\end{array}$ & & & $\begin{array}{c}0.212 \\
(0.043)\end{array}$ & & \\
\hline Industry Labor Intensity & $\begin{array}{c}0.813 \\
(0.035)\end{array}$ & & $\begin{array}{c}0.461 \\
(0.016)\end{array}$ & & & $\begin{array}{l}-0.352 \\
(0.018)\end{array}$ & & \\
\hline $\begin{array}{l}\text { City-Level Amenities x } \\
\text { Industry Labor Intensity }\end{array}$ & $\begin{array}{c}0.293 \\
(0.147)\end{array}$ & $\begin{array}{c}0.293 \\
(0.057)\end{array}$ & $\begin{array}{l}-0.129 \\
(0.065)\end{array}$ & $\begin{array}{l}-0.043 \\
(0.041)\end{array}$ & $\begin{array}{l}-0.128 \\
(0.039)\end{array}$ & $\begin{array}{c}0.053 \\
(0.069)\end{array}$ & $\begin{array}{c}0.128 \\
(0.046)\end{array}$ & $\begin{array}{c}0.069 \\
(0.046)\end{array}$ \\
\hline $\begin{array}{l}\text { Log } 1992 \text { Total Employment } \\
\text { in City-Industry }\end{array}$ & & & $\begin{array}{c}0.763 \\
(0.005)\end{array}$ & $\begin{array}{c}0.408 \\
(0.009)\end{array}$ & $\begin{array}{c}0.789 \\
(0.013)\end{array}$ & $\begin{array}{c}0.824 \\
(0.006)\end{array}$ & $\begin{array}{c}0.484 \\
(0.011)\end{array}$ & $\begin{array}{c}0.746 \\
(0.018)\end{array}$ \\
\hline $\begin{array}{l}\text { Log } 1992 \text { Av. Establishment } \\
\text { Size in Region-Industry }\end{array}$ & & & & & $\begin{array}{l}-0.669 \\
(0.021)\end{array}$ & & & $\begin{array}{l}-0.460 \\
(0.027)\end{array}$ \\
\hline Adjusted R-Squared & 0.04 & 0.81 & 0.66 & 0.87 & 0.88 & 0.58 & 0.81 & 0.81 \\
\hline City Fixed Effects & & $X$ & & $X$ & $\mathrm{X}$ & & $\mathrm{X}$ & $X$ \\
\hline Industry Fixed Effects & & $X$ & & $X$ & $X$ & & $X$ & $X$ \\
\hline
\end{tabular}

Notes: Estimations quantify the relationships among city amenities, industry labor intensity, industry location, and entrepreneurship. The dependent variables in columns 1 and 2 are log employments by city-industry taken from the LBD. These specifications describe industrial location patterns. The dependent variables in columns 3-8 are log entry employments of new firms or facility expansions by city-industry. These specifications describe subsequent entrepreneurship rates. Entry employments are annual averages for city-industries over the 1992-1999 period. Average entry of less than one worker is recoded as one worker for these estimations. Cities are classified by 273 PMSAs excluding $\mathrm{AK}$ and HI, and industries are classified at the SIC2 level (66 in total). City-level amenities are calculated through 1990 housing prices and climate variables as described in the text and appendix. Industry labor intensity is measured as payroll divided by total sales. Total employments are calculated from initial values in 1992 by city-industry.

Explanatory variables are demeaned prior to interaction to restore main effects. Estimations report robust standard errors and are unweighted. Columns 1 and 2 have 18,018 observations. Columns 3-8 have 16,363 observations after dropping city-industries where no initial employment existed. Weighted regressions employing an interaction of average industry size across cities with average size of industries within a city as weights produce similar results. 
Table 9: Amenities, Education, Industry Location, and Entrepreneurship

\begin{tabular}{|c|c|c|c|c|c|c|}
\hline & $\begin{array}{l}\text { Total } \\
\text { Employment }\end{array}$ & $\begin{array}{l}\text { Total } \\
\text { Employment }\end{array}$ & $\begin{array}{l}\text { Startup } \\
\text { Entry }\end{array}$ & $\begin{array}{l}\text { Startup } \\
\text { Entry }\end{array}$ & $\begin{array}{l}\text { Facility } \\
\text { Expansions }\end{array}$ & $\begin{array}{l}\text { Facility } \\
\text { Expansions }\end{array}$ \\
\hline & $(1)$ & $(2)$ & (3) & (4) & (5) & (6) \\
\hline & \multicolumn{6}{|c|}{$\begin{array}{c}\text { Dependent Variable is Log Employment in Indicated Type } \\
\text { of Establishment over 1992-1999 by City-Industry }\end{array}$} \\
\hline City-Level Amenities & $\begin{array}{c}0.972 \\
(0.225)\end{array}$ & & $\begin{array}{c}0.158 \\
(0.027)\end{array}$ & & $\begin{array}{l}-0.038 \\
(0.042)\end{array}$ & \\
\hline $\begin{array}{l}\text { City-Level Bachelors' Share } \\
\text { in } 1990\end{array}$ & $\begin{array}{l}2.250 \\
(0.178)\end{array}$ & & $\begin{array}{c}0.269 \\
(0.024)\end{array}$ & & $\begin{array}{c}0.388 \\
(0.035)\end{array}$ & \\
\hline $\begin{array}{l}\text { Industry Share of Workers } \\
\text { with Bachelors' Education }\end{array}$ & $\begin{array}{c}0.440 \\
(0.030)\end{array}$ & & $\begin{array}{l}-0.223 \\
(0.011)\end{array}$ & & $\begin{array}{l}-0.075 \\
(0.018)\end{array}$ & \\
\hline $\begin{array}{l}\text { City-Level Amenities x } \\
\text { Industry Bach. Intensity }\end{array}$ & $\begin{array}{c}0.199 \\
(0.125)\end{array}$ & $\begin{array}{c}0.199 \\
(0.052)\end{array}$ & $\begin{array}{c}0.049 \\
(0.042)\end{array}$ & $\begin{array}{c}0.052 \\
(0.033)\end{array}$ & $\begin{array}{c}0.271 \\
(0.072)\end{array}$ & $\begin{array}{c}0.287 \\
(0.048)\end{array}$ \\
\hline $\begin{array}{l}\text { City-Level Bach. Share x } \\
\text { Industry Bach. Intensity }\end{array}$ & $\begin{array}{c}0.578 \\
(0.099)\end{array}$ & $\begin{array}{c}0.578 \\
(0.046)\end{array}$ & $\begin{array}{c}0.069 \\
(0.037)\end{array}$ & $\begin{array}{c}0.159 \\
(0.029)\end{array}$ & $\begin{array}{c}0.164 \\
(0.059)\end{array}$ & $\begin{array}{c}0.268 \\
(0.039)\end{array}$ \\
\hline $\begin{array}{l}\text { Log } 1992 \text { Av. Establishment } \\
\text { Size in Region-Industry }\end{array}$ & & & $\begin{array}{l}-0.827 \\
(0.009)\end{array}$ & $\begin{array}{l}-0.660 \\
(0.021)\end{array}$ & $\begin{array}{l}-0.526 \\
(0.013)\end{array}$ & $\begin{array}{l}-0.452 \\
(0.027)\end{array}$ \\
\hline $\begin{array}{l}\text { Log } 1992 \text { Total Employment } \\
\text { in City-Industry }\end{array}$ & & & $\begin{array}{c}0.966 \\
(0.004)\end{array}$ & $\begin{array}{c}0.779 \\
(0.013)\end{array}$ & $\begin{array}{c}0.935 \\
(0.006)\end{array}$ & $\begin{array}{c}0.732 \\
(0.018)\end{array}$ \\
\hline Adjusted R-Squared & 0.04 & 0.81 & 0.79 & 0.88 & 0.63 & 0.81 \\
\hline City Fixed Effects & & $X$ & & $X$ & & $X$ \\
\hline Industry Fixed Effects & & $\mathrm{X}$ & & $\mathrm{X}$ & & $X$ \\
\hline
\end{tabular}

Notes: See Table 8. City and industry education shares taken from 1990 Census. 
Table A1: Entry Rates and Regional Industrial Structure

\begin{tabular}{|c|c|c|c|c|c|c|}
\hline & $\begin{array}{l}\text { Startup } \\
\text { Entry }\end{array}$ & $\begin{array}{l}\text { Startup } \\
\text { Entry }\end{array}$ & $\begin{array}{l}\text { Startup } \\
\text { Entry }\end{array}$ & $\begin{array}{l}\text { Facility } \\
\text { Expansions }\end{array}$ & $\begin{array}{l}\text { Facility } \\
\text { Expansions }\end{array}$ & $\begin{array}{c}\text { Facility } \\
\text { Expansions }\end{array}$ \\
\hline & $(1)$ & $(2)$ & (3) & (4) & $(5)$ & (6) \\
\hline & \multicolumn{6}{|c|}{$\begin{array}{l}\text { Dep. Variable is Log Average Employment in Entering } \\
\text { Establishments over 1992-1999 by Region-Industry }\end{array}$} \\
\hline & \multicolumn{6}{|c|}{ Entry and Small Firm Share } \\
\hline $\begin{array}{l}\text { Log } 1992 \text { Total Employment } \\
\text { in Region-Industry }\end{array}$ & $\begin{array}{c}0.976 \\
(0.013)\end{array}$ & $\begin{array}{c}0.758 \\
(0.036)\end{array}$ & $\begin{array}{c}0.972 \\
(0.011)\end{array}$ & $\begin{array}{l}1.090 \\
(0.015)\end{array}$ & $\begin{array}{c}0.838 \\
(0.038)\end{array}$ & $\begin{array}{c}1.069 \\
(0.017)\end{array}$ \\
\hline $\begin{array}{l}\text { Log } 1992 \text { Small Firm Share } \\
\text { in Region-Industry }\end{array}$ & $\begin{array}{c}0.543 \\
(0.018)\end{array}$ & $\begin{array}{c}0.400 \\
(0.043)\end{array}$ & $\begin{array}{c}0.512 \\
(0.024)\end{array}$ & $\begin{array}{c}0.181 \\
(0.027)\end{array}$ & $\begin{array}{c}0.069 \\
(0.065)\end{array}$ & $\begin{array}{l}-0.023 \\
(0.015)\end{array}$ \\
\hline Adjusted R-Squared & 0.84 & 0.93 & & 0.69 & 0.88 & \\
\hline Region Fixed Effects & $\mathrm{X}$ & $\mathrm{X}$ & $\mathrm{X}$ & $\mathrm{X}$ & $\mathrm{X}$ & $\mathrm{X}$ \\
\hline Industry Fixed Effects & & $\mathrm{X}$ & & & $X$ & \\
\hline Estimation Technique & OLS & OLS & IV & OLS & OLS & IV \\
\hline
\end{tabular}

Notes: See Table 2. Estimations quantify the relationship between entry and the share of employees in establishments with 20 or fewer employees. The region with the least industry employment is excluded for each industry in both OLS and IV specifications. IV regressions instrument for observed region-industry small firm share with the 1992 value in the excluded region by industry. The first stage relationship is $0.837(0.014)$. 
Table A2: Entry Rates and Regional Industrial Structure by Sector

\begin{tabular}{|c|c|c|c|c|c|c|}
\hline & $\begin{array}{c}\text { Mining } \\
\text { and } \\
\text { Construction }\end{array}$ & $\begin{array}{l}\text { Manu- } \\
\text { facturing }\end{array}$ & $\begin{array}{l}\text { Transport. } \\
\text { \& Utilities }\end{array}$ & $\begin{array}{c}\text { Wholesale } \\
\text { \& Retail } \\
\text { Trade }\end{array}$ & $\begin{array}{c}\text { Finance, } \\
\text { Insurance, \& } \\
\text { Real Estate }\end{array}$ & Services \\
\hline & $(1)$ & $(2)$ & $(3)$ & $(4)$ & $(5)$ & $(6)$ \\
\hline & \multicolumn{6}{|c|}{$\begin{array}{l}\text { Dep. Variable is Log Average Employment in Entering } \\
\text { Establishments over 1992-1999 by Region-Industry }\end{array}$} \\
\hline $\begin{array}{l}\text { Log } 1992 \text { Total Employment } \\
\text { in Region-Industry }\end{array}$ & $\begin{array}{c}0.718 \\
(0.082)\end{array}$ & $\begin{array}{c}0.927 \\
(0.064)\end{array}$ & $\begin{array}{c}0.461 \\
(0.092)\end{array}$ & $\begin{array}{c}0.808 \\
(0.060)\end{array}$ & $\begin{array}{c}0.572 \\
(0.080)\end{array}$ & $\begin{array}{c}0.902 \\
(0.055)\end{array}$ \\
\hline $\begin{array}{l}\text { Log } 1992 \text { Av. Establishment } \\
\text { Size in Region-Industry }\end{array}$ & $\begin{array}{l}-0.701 \\
(0.195)\end{array}$ & $\begin{array}{l}-0.825 \\
(0.052)\end{array}$ & $\begin{array}{l}-0.361 \\
(0.143)\end{array}$ & $\begin{array}{l}-0.256 \\
(0.123)\end{array}$ & $\begin{array}{l}-0.214 \\
(0.158)\end{array}$ & $\begin{array}{l}-0.426 \\
(0.107)\end{array}$ \\
\hline Adjusted R-Squared & 0.94 & 0.85 & 0.93 & 0.96 & 0.90 & 0.97 \\
\hline $\begin{array}{l}\text { Region Fixed Effects } \\
\text { Industry Fixed Effects }\end{array}$ & $\begin{array}{l}X \\
X\end{array}$ & $\begin{array}{l}X \\
X\end{array}$ & $\begin{array}{l}X \\
X\end{array}$ & $\begin{array}{l}X \\
X\end{array}$ & $\begin{array}{l}X \\
X\end{array}$ & $\begin{array}{l}X \\
X\end{array}$ \\
\hline & \multicolumn{6}{|c|}{ B. Facility Expansions by Sector } \\
\hline $\begin{array}{l}\text { Log } 1992 \text { Total Employment } \\
\text { in Region-Industry }\end{array}$ & $\begin{array}{c}1.032 \\
(0.080)\end{array}$ & $\begin{array}{c}1.111 \\
(0.097)\end{array}$ & $\begin{array}{c}0.410 \\
(0.173)\end{array}$ & $\begin{array}{c}0.951 \\
(0.060)\end{array}$ & $\begin{array}{c}0.756 \\
(0.114)\end{array}$ & $\begin{array}{c}0.703 \\
(0.085)\end{array}$ \\
\hline $\begin{array}{l}\text { Log } 1992 \text { Av. Establishment } \\
\text { Size in Region-Industry }\end{array}$ & $\begin{array}{l}-0.577 \\
(0.361)\end{array}$ & $\begin{array}{l}-0.688 \\
(0.190)\end{array}$ & $\begin{array}{c}0.120 \\
(0.191)\end{array}$ & $\begin{array}{l}-0.091 \\
(0.129)\end{array}$ & $\begin{array}{l}-0.031 \\
(0.148)\end{array}$ & $\begin{array}{c}0.053 \\
(0.203)\end{array}$ \\
\hline Adjusted R-Squared & 0.85 & 0.74 & 0.89 & 0.96 & 0.92 & 0.95 \\
\hline Region Fixed Effects & $\mathrm{X}$ & $\mathrm{X}$ & $\mathrm{X}$ & $\mathrm{X}$ & $\mathrm{X}$ & $\mathrm{X}$ \\
\hline Industry Fixed Effects & $\mathrm{X}$ & $\mathrm{X}$ & $\mathrm{X}$ & $\mathrm{X}$ & $\mathrm{X}$ & $\mathrm{X}$ \\
\hline
\end{tabular}

Notes: See Table 2. Estimations are undertaken by sector. 
Table A3: Entry Size Distribution and Regional Industrial Structure

\begin{tabular}{|c|c|c|c|c|c|}
\hline & Total & & Entering & yment Of & \\
\hline & Entry & $1-5$ & $6-20$ & $21-100$ & $101+$ \\
\hline & $(1)$ & (2) & (3) & (4) & (5) \\
\hline & & $\begin{array}{l}\text { ariable is } \\
\text { lishment }\end{array}$ & $\begin{array}{l}\text { verage } E \\
992-199\end{array}$ & $\begin{array}{l}\text { lent in Er } \\
\text { gion-Ind }\end{array}$ & \\
\hline & & A. Entry & erage $\mathrm{Es}$ & ment Size & \\
\hline $\begin{array}{l}\text { Log } 1992 \text { Total Employment } \\
\text { in Region-Industry }\end{array}$ & $\begin{array}{c}0.810 \\
(0.036)\end{array}$ & $\begin{array}{c}0.616 \\
(0.036)\end{array}$ & $\begin{array}{c}0.718 \\
(0.033)\end{array}$ & $\begin{array}{c}0.764 \\
(0.075)\end{array}$ & $\begin{array}{c}0.779 \\
(0.086)\end{array}$ \\
\hline $\begin{array}{l}\text { Log } 1992 \text { Av. Establishment } \\
\text { Size in Region-Industry }\end{array}$ & $\begin{array}{l}-0.638 \\
(0.046)\end{array}$ & $\begin{array}{l}-0.805 \\
(0.049)\end{array}$ & $\begin{array}{l}-0.849 \\
(0.050)\end{array}$ & $\begin{array}{l}-0.606 \\
(0.095)\end{array}$ & $\begin{array}{l}-0.217 \\
(0.124)\end{array}$ \\
\hline Adjusted R-Squared & 0.93 & 0.98 & 0.96 & 0.89 & 0.65 \\
\hline Region Fixed Effects & $\mathrm{X}$ & $\mathrm{X}$ & $\mathrm{X}$ & $\mathrm{X}$ & $\mathrm{X}$ \\
\hline Industry Fixed Effects & $\mathrm{X}$ & $\mathrm{X}$ & $\mathrm{X}$ & $\mathrm{X}$ & $\mathrm{X}$ \\
\hline & & B. Entry & IHI Conc & n Index & \\
\hline $\begin{array}{l}\text { Log } 1992 \text { Total Employment } \\
\text { in Region-Industry }\end{array}$ & $\begin{array}{c}0.475 \\
(0.030)\end{array}$ & $\begin{array}{c}0.214 \\
(0.034)\end{array}$ & $\begin{array}{c}0.287 \\
(0.036)\end{array}$ & $\begin{array}{c}0.442 \\
(0.037)\end{array}$ & $\begin{array}{c}0.651 \\
(0.058)\end{array}$ \\
\hline $\begin{array}{l}\text { Log } 1992 \text { HHI Concentration } \\
\text { in Region-Industry }\end{array}$ & $\begin{array}{l}-0.167 \\
(0.021)\end{array}$ & $\begin{array}{l}-0.149 \\
(0.022)\end{array}$ & $\begin{array}{l}-0.179 \\
(0.019)\end{array}$ & $\begin{array}{l}-0.169 \\
(0.037)\end{array}$ & $\begin{array}{l}-0.098 \\
(0.045)\end{array}$ \\
\hline Adjusted R-Squared & 0.93 & 0.97 & 0.96 & 0.89 & 0.65 \\
\hline Region Fixed Effects & $\mathrm{X}$ & $\mathrm{X}$ & $\mathrm{X}$ & $\mathrm{X}$ & $\mathrm{X}$ \\
\hline Industry Fixed Effects & $\mathrm{X}$ & $\mathrm{X}$ & $\mathrm{X}$ & $X$ & $\mathrm{X}$ \\
\hline
\end{tabular}

Notes: See Table 3. Estimations include industry fixed effects and regional fixed effects. 
Table A4: Labor Returns and Regional Industrial Structure by Sector

\begin{tabular}{|c|c|c|c|c|c|c|}
\hline & $\begin{array}{c}\text { Mining } \\
\text { and } \\
\text { Construction }\end{array}$ & $\begin{array}{c}\text { Manu- } \\
\text { facturing }\end{array}$ & $\begin{array}{l}\text { Transport. } \\
\text { \& Utilities }\end{array}$ & $\begin{array}{c}\text { Wholesale } \\
\text { \& Retail } \\
\text { Trade }\end{array}$ & $\begin{array}{c}\text { Finance, } \\
\text { Insurance, \& } \\
\text { Real Estate }\end{array}$ & Services \\
\hline & $(1)$ & $(2)$ & (3) & (4) & $(5)$ & (6) \\
\hline & \multicolumn{6}{|c|}{ A. Log 1997 Labor Returns in Single-Unit Firms in Region-Industry } \\
\hline $\begin{array}{l}\text { Log } 1992 \text { Total Employment } \\
\text { in Region-Industry }\end{array}$ & $\begin{array}{c}0.089 \\
(0.039)\end{array}$ & $\begin{array}{c}0.043 \\
(0.027)\end{array}$ & $\begin{array}{c}0.042 \\
(0.064)\end{array}$ & $\begin{array}{c}0.102 \\
(0.032)\end{array}$ & $\begin{array}{c}0.034 \\
(0.073)\end{array}$ & $\begin{array}{c}0.005 \\
(0.032)\end{array}$ \\
\hline $\begin{array}{l}\text { Log } 1992 \text { Av. Establishment } \\
\text { Size in Region-Industry }\end{array}$ & $\begin{array}{l}-0.072 \\
(0.169)\end{array}$ & $\begin{array}{l}-0.032 \\
(0.045)\end{array}$ & $\begin{array}{l}-0.090 \\
(0.111)\end{array}$ & $\begin{array}{c}0.020 \\
(0.048)\end{array}$ & $\begin{array}{c}0.103 \\
(0.141)\end{array}$ & $\begin{array}{c}0.068 \\
(0.037)\end{array}$ \\
\hline Adjusted R-Squared & 0.49 & 0.64 & 0.80 & 0.97 & 0.75 & 0.94 \\
\hline Region Fixed Effects & $\mathrm{X}$ & $\mathrm{X}$ & $\mathrm{X}$ & $\mathrm{X}$ & $\mathrm{X}$ & $\mathrm{X}$ \\
\hline \multirow[t]{2}{*}{ Industry Fixed Effects } & $\mathrm{X}$ & $\mathrm{X}$ & $\mathrm{X}$ & $\mathrm{X}$ & $\mathrm{X}$ & $\mathrm{X}$ \\
\hline & \multicolumn{6}{|c|}{ B. Log 1997 Labor Returns in Multi-Unit Firms in Region-Industry } \\
\hline $\begin{array}{l}\text { Log } 1992 \text { Total Employment } \\
\text { in Region-Industry }\end{array}$ & $\begin{array}{c}0.064 \\
(0.055)\end{array}$ & $\begin{array}{c}0.080 \\
(0.028)\end{array}$ & $\begin{array}{l}-0.020 \\
(0.053)\end{array}$ & $\begin{array}{l}-0.025 \\
(0.042)\end{array}$ & $\begin{array}{c}0.064 \\
(0.130)\end{array}$ & $\begin{array}{l}-0.001 \\
(0.030)\end{array}$ \\
\hline $\begin{array}{l}\text { Log } 1992 \text { Av. Establishment } \\
\text { Size in Region-Industry }\end{array}$ & $\begin{array}{l}-0.012 \\
(0.070)\end{array}$ & $\begin{array}{l}-0.001 \\
(0.041)\end{array}$ & $\begin{array}{l}-0.122 \\
(0.103)\end{array}$ & $\begin{array}{c}0.124 \\
(0.079)\end{array}$ & $\begin{array}{c}0.137 \\
(0.134)\end{array}$ & $\begin{array}{c}0.042 \\
(0.069)\end{array}$ \\
\hline Adjusted R-Squared & 0.79 & 0.78 & 0.83 & 0.96 & 0.81 & 0.91 \\
\hline Region Fixed Effects & $\mathrm{X}$ & $\mathrm{X}$ & $\mathrm{X}$ & $\mathrm{X}$ & $\mathrm{X}$ & $\mathrm{X}$ \\
\hline Industry Fixed Effects & $\mathrm{X}$ & $\mathrm{X}$ & $\mathrm{X}$ & $X$ & $\mathrm{X}$ & $\mathrm{X}$ \\
\hline
\end{tabular}

Notes: See Table 4. Estimations are undertaken by sector. 
Table A5: Amenities and Housing Prices

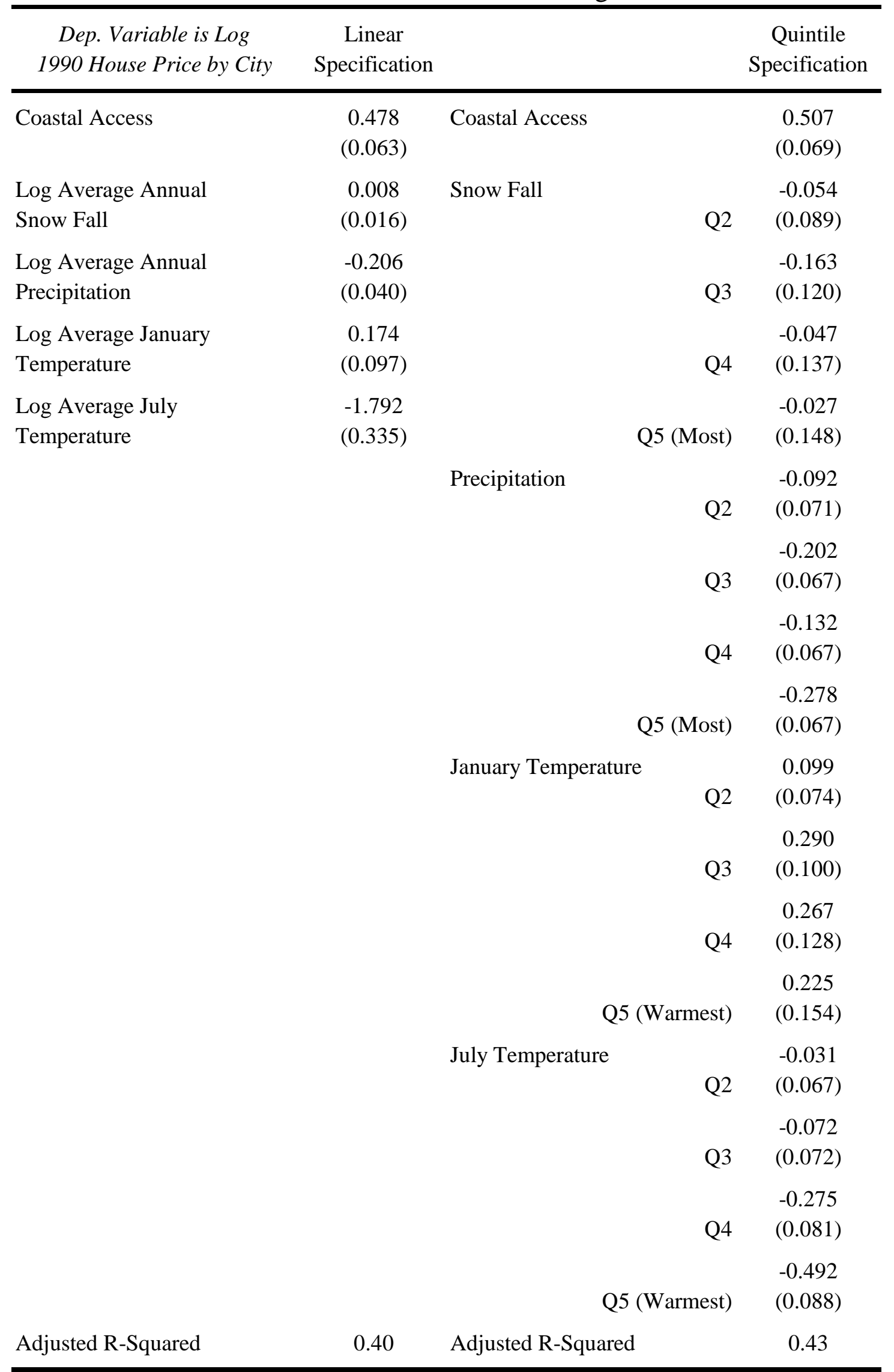

Notes: Estimations consider log housing prices by city taken from the 1990 Census. Predicted values from the regressions are used as composite amenities variables in main specifications. Estimations contain 275 observations and report robust standard errors. 


\section{Table A6: Climate-Based Amenities v. Traditional Natural Advantages}

Pairwise Correlation of Climate Amenities

Pairwise Correlation of Labor Intensity and Other Natural Advantages by State and Other Dependencies by Industry

\begin{tabular}{lclr}
\hline Electricity Affordability & -0.301 & Electricity Intensity & 0.010 \\
Natural Gas Affordability & -0.407 & Natural Gas Intensity & -0.036 \\
Coal Affordability & -0.476 & Coal Intensity & -0.019 \\
Farmland Percentage & -0.534 & Livestock Intensity & -0.095 \\
Timberland Percentage & 0.222 & Lumber Intensity & 0.245 \\
Population Density & 0.340 & Final Cons. Sales Intensity & -0.114 \\
\hline
\end{tabular}

Notes: The first column presents pairwise correlations between calculated climate-based amenities and other forms of natural advantages at the state level excluding AK and HI. The second column presents pairwise correlations between labor intensity of industries, measured as payroll divided by sales, and other dependencies for manufacturing industries. These latter data are only available for the manufacturing sector. 